\title{
Proto-basement in Svalbard
}

\author{
W. B. HARLAND
}

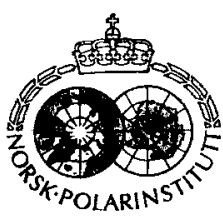

Harland, W. B. 1997: Proto-basement in Svalbard. Polar Research 16(2), 123-147.

Candidates for possible Precambrian proto-basement throughout Svalbard are considered and evaluated. The paper provides a tectono-stratigraphic framework for consideration of new data. Proto-basement, in the sense of basement in Proterozoic time, implies the occurrence of a Precambrian tectonic event. Vendian rocks are widespread in Svalbard and, because there is no known Vendian major tectonic event, the search is narrowed to pre-Vendian rocks. The approach is primarily tectono-stratigraphic, to identify a significant break by unconformity, contrast in metamorphic facies and isotopic age determinations.

The paper concludes that the following rock units are proto-basement: Isbjømhamna and (newly defined) Eimfjellet groups, Nordbukta Group, Magnethøgda Group, the Richarddalen Complex; the Atomfjella Complex, the Brennevinsfjorden Group and the granitoids related to the Kapp Hansteen Group and the Duvefjorden Complex. While considered unlikely to be proto-basement the following cannot be ruled out: the Mefonntoppane and Kistefjellet rocks and the Sigfredbogen unit, the blue-schist Vestgotabreen rocks, the Pinkie Formation and parts of the Kongsvegen Group.

Terrane implications are consistent with the three terrane model of Harland \& Wright (1979), modified by Harland et al. (1993); but the data presented here hardly constrain such a model. In so far as the conclusions here are valid the effect is to subtract from, rather than add to, the outcrops commonly mapped as likely proto-basement.

W. B. Harland, Department of Earth Sciences, University of Cambridge, Downing Street, Cambridge CB2 $2 E Q$, U.K.

\section{Introduction}

This paper reviews the current status of the longstanding problem of identifying basement within various Precambrian successions in Svalbard. Basement in this sense must be formed by Precambrian tectogenesis. Basement may result in a clear unconformity within a Precambrian succession unless (1) the later Precambrian cover rocks have been removed, (2) the Precambrian rocks were never deposited there, or (3) the unconformity has itself been obscured during a later tectonic episode.

A problem arises because much of Svalbard has undergone intense Early to mid-Paleozoic deformation, metamorphism and, in places, migmatisation and granite intrusion. These events are commonly referred to as Caledonian, though structures may better be discriminated as Ordovician (M'Clintock or Eidembreen phase) Silurian (Ny Friesland), Early Devonian (Haakonian and Monacobreen) Late Devonian (Svalbardian) or Devono-Carboniferous (Ellesmerian). Many of the rocks so tectonised were formed in Precambrian time. They form the basement to the Devonian or Carboniferous through Cenozoic cover rocks.
The object of this paper is to investigate evidence for Precambrian tectonism within the Paleozoic or Paleogene tectonised Precambrian rocks. To avoid confusion the unambiguous term proto-basement is applied here throughout. Isotopic ages are relevant to, but only a part of, such a tectono-stratigraphic enquiry. Precise values are not necessary.

During the last century, all metamorphic basement would commonly have been designated as Archean. Nathorst (in Suess, 1888) made the distinction (not as now, meaning an age greater than $2500 \mathrm{Ma}$ ) both in northeast and in northwest Spitsbergen, distinguishing Archean from Nordenskiöld's Hecla Hoek.

In this survey Vendian strata are distinguished (Fig. 1). They are widespread in Svalbard and correlated mainly by their contained tillites and occasional biotas. Vendian age is applied here in Svalbard according to arguments in Harland et al. (1993). Even though there is disagreement on the age of some alleged Vendian strata there is generally little argument as to the absence of a significant break such as a regional unconformity in those alleged Vendian sequences. Therefore, the "candidates" are sought mostly amongst preVendian rocks as mapped here. Alternative views 
as to the ages of rocks mapped here as Vendian are also mentioned.

Two areas of migmatites, once thought to be Archean basement, from the pioneer work of Holtedahl $(1912,1914)$ in the northwest and of Kulling (1934) and Norsk Polarinstitutt geologists in the northeast, were recognised as "Caledonian", even though the northeastern paleosomes were probably proto-basement. Isotopic ages confirmed these interpretations of almost ubiquitous midPaleozoic thermal events but with increasing evidence for proto-basement from inherited resistant zircons.

\section{Review of candidates}

\section{Bjфrnøya}

Below the Younger Dolomite Series (Canadian) are the Slate Quartzite Series, $175 \mathrm{~m}$, and the Older Dolomite Series, $500+\mathrm{m}$, of Holtedahl (1920). These, renamed as follows by Krasil'shchikov \& Livshits (1974), are candidates: Sørhamna Formation, $175 \mathrm{~m}$ (?Vendian e.g. as argued Harland et al. 1993); Russehamna Formation, $500+m$, described by Krasil'shchikov \& Mil'shtein (1975) with 5 members of which part of 3 plus 4 and 5 are probably Vendian. The lower members 3 to 1 may thus be Sturtian (Late Riphean). They placed an unconformity beneath the Sørhamna Formation. On the other hand Harland et al. (1993) identified an unconformity above it. Below it a discordance is not necessary, nor is there obvious structural contrast except for the incompetent behaviour of the Sørhamna slates and phyllites between massive carbonate formations. Even if there were a latest Precambrian break it would hardly identify proto-basement.

\section{Sørkapp Land}

Sørkapp Land was mapped by Major \& Winsnes (1955), in more detail by Winsnes et al. (1992) and with accompanying text by Dallmann et al. (1993) and to which numbered map units refer here.

The boundary between Early Cambrian and the underlying Gåshamna Formation is generally tectonic. But there is almost certainly a hiatus and minor unconformity where a sedimentary contact is seen. However the Cambro-Ordovician succession is not known to rest on units beneath the Gåshamna Formation except at one point where Birkenmajer (1991, p. 275, locality 9) suggested that the Early Cambrian Blasstertoppen Formation may rest unconformably on Höferpynten Formation. That locality is mapped (Winsnes et al. 1992, map C13G) not as Höferpynten but as unit 34 which is part of the rocks considered below under candidate (b).

Birkenmajer's Jarlsbergian Diastrophism $(1975,1991)$ appears not to have been sufficiently intense to disturb the essential relationship between the older and younger strata to require that the Gashamna Formation, and therefore all the adjacent Precambrian strata, are proto-basement. The above argument hardly affects the difference of opinion as to the age of the Gåshamna Formation which Harland et al. (1993) considered as probable Late Vendian and by Dallmann et al. (1993) as pre-Vendian. Otherwise three outcrops merit consideration as candidates for proto-basement. (a) Höferpynten Formation (unit 31) (b) units 34-38 (c) units 32 and 33.

(a) Höferpynten Formation, $>710 \mathrm{~m}$. - On the north coast of Sørkapp Land (southwest Hornsund) the Höferpynten Formation is of limited but conspicuous outcrop with high cliffs at its eponymous locality. Winsnes (in Major \& Winsnes, 1955) showed it to be in faulted contact with adjacent rocks. It has been correlated with the Akademikerbreen Group of Ny Friesland which is largely pre-Vendian (Harland \& Wilson, 1956; Birkenmajer, 1958, 1975; Knoll 1982, Knoll et al. 1989) and the Ryssö Formation of Nordaustlandet (Knoll \& Calder 1983). Birkenmajer (1958, 1975) also correlated it with the Fannytoppen Formation to the north across Hornsund which he regarded as in sequence with, and older than, the (possibly Ediacara) Gåshamna Formation phyllite. [Correlation with similar facies at Dunøyane does not help as those islands are isolated.]

Harland et al. (1993), following Harland (1978), did not agree with the earlier correlation of the Höferpynten Formation with their Fannytoppen Formation. This had extended the Höferpynten Formation northwards through Wedel Jarlsberg Land as was adopted in the map B 12G, Torellbreen (Ohta \& Dallmann 1991-1996). Radical differences in interpretation are discussed elsewhere (Harland in press). Nevertheless considering the lack of metamorph- 


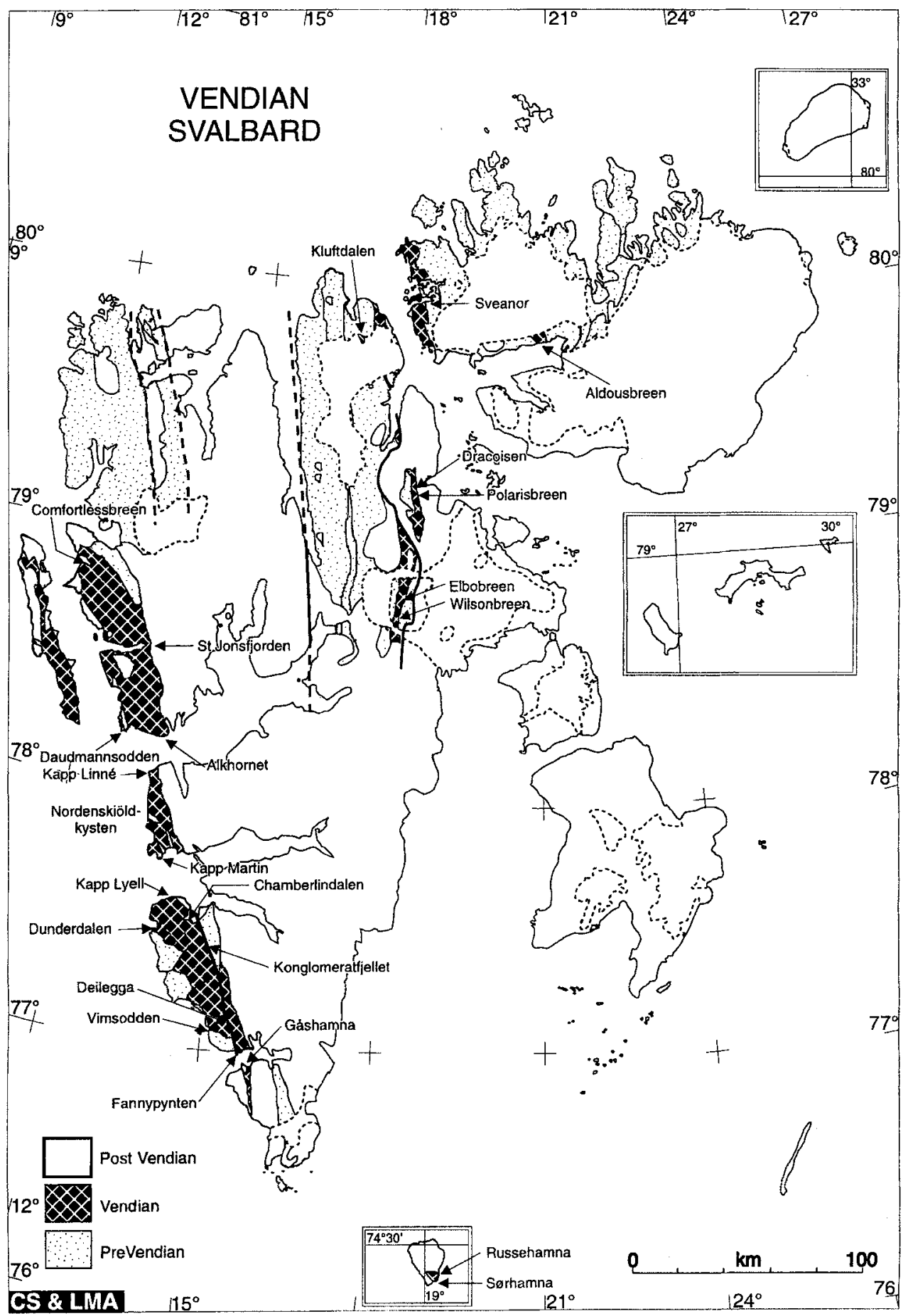

Fig. 1. Vendian outcrops of Svalbard based mainly on Harland, Hambrey \& Waddams (1993). Because no significant tectonism has been established for Vendian time the search for proto-basement avoids these in favour of pre-Vendian rocks. The conclusions of Harland et al. may be controversial but in so far as they were argued in detail and have not yet been challenged by argument from evidence they are provisionally accepted here. 
ism of the Höferpynten Formation in spite of an intervening fault, the lack of tectonisation and the approximate concordance with the Gåshamna Formation, there is no strong case for it being considered as basement. The faulted contact between the overturned Höferpynten carbonates and the younger underlying Gasshamna phyllite does not suggest any major discordance.

(b) Mefonntoppane and Kistefjellet belt (1992 map C13G units 34-38). - A belt of discontinuous mountains east of Samarinbreen and Olsokbreen runs from Påskefjella in the north, through Mefonntoppane to Kistefjellet in southernmost Sørkapp Land. The rocks are shown as five numbered map units (Winsnes et al. 1992) and described in the legend as follows: units 34 predominantly carbonate rock; 35, phyllites and mica schists - some with garnets; 36, quartzite; 37, marble; 38, quartzite and garnet mica schist.

They are overlain unconformably by Devonian, Carboniferous and by Triassic strata. The presumption is that they are Precambrian. Brief notes by Birkenmajer (1993), from visits with W. K. Dallmann and Y. Ohta in 1990, suggested correlation with rocks described by him northwest of Isbjørnhamna namely: unit 38 with Gulliksenfjellet and Steinvikskardet formations and Unit 37 with the Ariekammen Formation. These belong to the Eimfjellet and Isbjørnhamna Groups respectively which are pre-Vendian basement. Birkenmajer suggested that unit 34 correlates with the Höferpynten Formation discussed above. Unit 34 to 36 are separated from the others and 35 might correspond with the Gashamna phyllites.

In any case the similarity of facies makes it reasonable to consider these rocks as candidates for proto-basement. Nevertheless, their ordered arrangement east of the mountains with outcrops sub-parallel to Cambrian and Ordovician strata does not suggest that a major orogenic event separated them. Moreover, considerations of Harland et al. (1993) would question such a correlation between terranes east and west of the Hansbreen Fault Zone. On that basis the Höferpynten correlation might be safe but not units 36 , 37 and 38 . The question of proto-basement here thus remains open.

(c) Sigfredbogen rocks: Map C13G (Winsnes et al. 1992) units 32 and 33. - The above name was given to these rocks to facilitate discussion of correlation (Harland, 1978; Harland et al. 1993).
They were originally mapped (Birkenmajer 1959 et seq.) as two units named from north of Hornsund: the Slyngfjellet Conglomerate (map unit 32) and the Deilegga Group (map unit 33). The correlation of these rocks has been questioned (Harland, 1978; Harland et al. 1993). They are taken here as upper and lower members of a postulated independent Sigfredbogen formation. Both members represent a similar grade of highly sheared meta-conglomerates $(\sim 10 \mathrm{~m})$ and metapsammites $(\sim 300 \mathrm{~m})$ in an outcrop bounded by faults. The shearing and indeed the metamorphism could be Paleozoic or Precambrian.

Harland et al. (1993) (contra Birkenmajer 1958 through 1993 and Ohta \& Dallmann 1992 et seq.) argued that the Deilegga Group and Slyngfjellet rocks north of Hornsund are early Varanger (early Vendian) in age. They are not so highly metamorphosed as the Sigfredbogen rocks. They thought that the latter might be older but gave no evidence as to their age. Winsnes et al. (1992 map C13G) made the Deilegga Group old enough to be serious candidates for basement. The intense shearing of the Sigfredbogen rocks could reflect their locus in the postulated Kongsfjorden-Hansbreen Fault Zone. The Sigfredbogen rocks certainly are likely candidates but Harland et al. thought that the Deilegga Group rocks, as developed north of Hornsund, are not.

\section{Wedel Jarlsberg Land}

Four strong candidates crop out in Wedel Jarlsberg Land: (a), (b), (c) and (d) below.

(a) Isbjornhamna Group, $>2.7 \mathrm{~km}$. - The three formations of the Isbjørnhamna Group form the mountains between Hansbreen and Werenskioldbreen. Birkenmajer (1958 et seq.) made them the oldest rocks in that area and his map (1990) shows an unconformity with Eimfjellet Group strata overstepping both Isbjørnhamna Group rocks and the Gulliksenfjellet Quartzite Formation. K-Ar dating of the garnet mica schists of the Skoddefjellet Formation suggested 565 and $594 \mathrm{Ma}$ (both Precambrian ages) for their metamorphism (Gayer et al. 1966). A preliminary $\mathrm{Rb}-\mathrm{Sr}$ whole rock age for schists of the Isbjørnhamna Group is $930 \mathrm{Ma}$ (Balashov et al. 1995). The upper intercept ages show this to be a reworking with inherited zircons of $2.5 \mathrm{Ga}$, as indicated by Balashov et al. (1993). Dallmann et al. (1993) on p. 42 of the text to map 
C13G refer to unpublished $\mathrm{Rb}-\mathrm{Sr}$ age of $940 \mathrm{Ma}$ by Teben'kov et al. (in prep.).

(b) Eimfjellet Group. - It now seems that neither the scheme of Birkenmajer (1960 through 1993a) nor that of Harland, Hambrey \& Waddams (1993) nor of Ohta \& Dallmann (1992 et seq.) accounted adequately for the succession between the Elveflya Formation (with tilloids) and the Isbjørnhamna Group. The map by Czerny et al. (1992) details a concordant sequence (from the latter to a discontinuity at the Vimsodden-Kosibapasset Fault) comprising six formations from the top: Pyttholmen, Gulliksenfjellet, Bratteggdalen, Skålfjellet, Eimfjellbreane and Skjerstranda resting concordantly on the top formation of the Isbjørnhamna Group. This is their Eimfjellet Group.

Balashov et al. (1995), from the Pythholmen Formation at the top of the Eimfjellet Group, recorded $\mathrm{U}-\mathrm{Pb}$ zircon ages of acid volcanics indicating a regional metamorphic event at about $930 \mathrm{Ma}$ affecting rocks originating at about $1200 \mathrm{Ma}$ with inherited zircon ages of about $2500 \mathrm{Ma}$. These data link the Eimfjellet Group (of Czerny et al.) closely with the Isbjørnhamna Group.

For the succession from the Elveflya Formation upwards Harland et al. agreed with Birkenmajer rather than Czerny et al. in the order of strata, but differed in regarding them all as Varanger in age, whereas Birkenmajer (1958-1992) and Ohta \& Dallmann (1992) treated them as basement from the Slyngfjellet Formation down. The conclusion here is summarised below:

(4) Aust Torellbreen Group (Werenskiöld Group of Harland et al. 1993) of Varanger age is suggested here to accommodate the Slyngfjellet, Deilegga, Jens Erikfjellet, Elveflya units of Berkenmajer (1993);

(3) Discontinuity, a faulted unconformity, (Vimsodden-Kosibapasset Fault) of Czerny et al. (1992);

(2) Eimfjellet Group of Czerny et al. (1992) proto-basement;

(1) Isfjordhamna Group of Birkenmajer (1958 et seq.) - proto-basement.

(c) Nordbukta Group, 3+ km. - North of Torellbreen, Bjørnerud (1990) and her colleagues mapped the Nordbukta Group (sequence), showing it to have been overfolded and truncated by an unconformable cover of the thin $(0-100 \mathrm{~m})$ Thiisfjellet Formation (map unit 39 of Ohta \& Dallmann, 1992) immediately underlying the Fløykalven tilloid (map unit 38). This was correlated as Early Varanger by Harland et al. (1993). Structural evidence of orogenic type deformation establishes the group as proto-basement by the erosion and unconformable cover of strata, which are no younger than Vendian (Bjørnerud et al. 1990). (The unconformity probably marks the Torellian diastrophism of Birkenmajer (1975).)

The above results are unified in the $1: 100,000$ geological map Sheet Bl1G (Dallmann et al. 1990) where the Nordbukta sequence is shown as map units 40 to 48 . That sequence of more than $3000 \mathrm{~m}$ is demonstrably Precambrian proto-basement of unknown age (Table 1).

Table 1. Nordbukta Group (proto-basement), B11G map units (and B12G map units in parentheses).

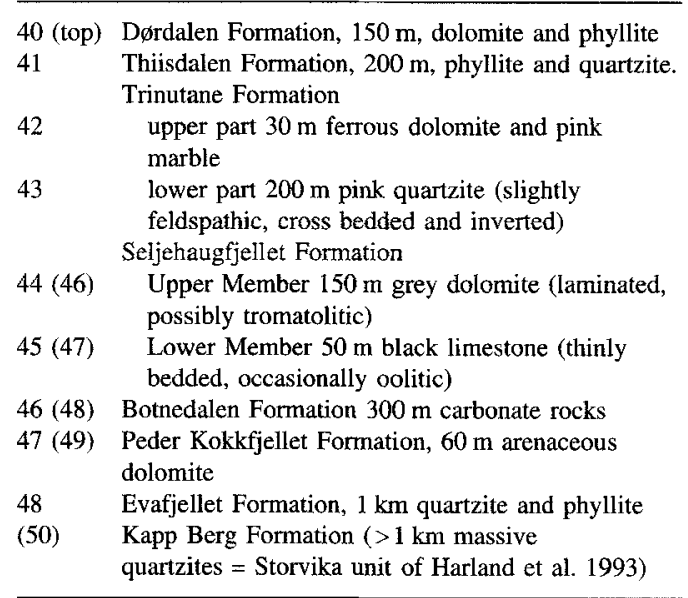

(d) Magnethøgda Group [(=Antoniabreen sequence as used privately by E. Hauser)]. Harland (1978) correlated the metamorphic rocks east of Recherchefjorden with the Isbjørnhamna Group. Bjørnerud et al. (1990) correlated them with the Nordbukta Group. It seems that Dallmann et al. (1990) on further consideration have not pressed that correlation. The map units of the sequence are there numbered 49 to 55 but are not claimed to be in that stratigraphic order. The conspicuous feldspathic gneisses and marbles have no other matching counterpart in Wedel Jarlsberg Land and their contacts with other Precambrian rocks are either faulted or obscured. 
Table 2. Magnethøgda Group.

$800 \mathrm{~m}$ undifferentiated carbonate rocks (51) with phyllite

$200 \mathrm{~m}$ dark phyllite (53) with quartzite

$>500 \mathrm{~m}$ augen gneiss and feldspathic quartzite (49)

$1400 \mathrm{~m}$ massive dolostone with pink marbles (50) with phyllite (53) and a marker band of sedimentary iron ore

$1200 \mathrm{~m}$ quartzite (54) and alternating quartzite/phyllite. (?bottom)

Dallmann et al. (1990) listed the (numbered) rock units in their uncertain succession thus (based on the work of A. Hjelle and E. Hauser).

Of the six units, 49 is the most distinctive. "The most feldspar-rich variants have been found in the western part of the Berzeliustinden area. The composition includes microcline, plagioclase and recrystallised quartz in a matrix of quartz, green biotite, muscovite, epidote, chlorite and rare garnet. Grain textures indicate that many of the feldspar grains probably are of sedimentary origin". Inverted cross bedding and isoclinal folding leave overall way-up and thickness uncertain (Dallmann et al. 1990). However the Torellbreen sheet (B12G. Ohta \& Dallmann 1996) suggests that the feldspathic rocks due south are in faulted contact with Gåshamna and even Cambrian formations which as argued by Harland et al. (1993) would be post-Varanger.

A structural study suggested that lineations parallel to regional fold axes are sub-parallel to high shear strains and flattening. A nappe structure was suspected, but no orientation or sense of shear data were reported (Rector \& Bjørnerud 1987).

The rocks are serious contenders for protobasement. They show a markedly higher degree of tectonism than Vendian rocks in southern Spitsbergen. [Ohta (pers. comm.) reported that similar pink marble and augen gneiss clasts are found in the Konglomeratfjellet conglomerate of Orvinfjella.]

(e) Other claims. - Whereas there may be little doubt as to (a), (b), (c) and (d) above, being protobasement, there are differences between authors as to the correlation of the overlying rocks.

(i) On Birkenmajer's (e.g. 1991, 1992, 1993a) scheme all Precambrian rocks would constitute at least three tectonic generations of proto-basement separated by Jarlsbergian, Torellian, and Werenskiöldian diastrophic episodes; the Slyngfjellet
Conglomerate is not correlated with glacigenic rocks whereas the Vimsodden tilloid was so regarded at first but questioned (1990) and it was taken to be much older than the Varanger tillites.

(ii) Harland et al. (1993) correlated the two members of Birkenmajer's Slyngfjellet Conglomerate east of Hansbreen with the Early and Late Varanger glacial episodes and, together with the Deilegga and Jens Erikfjellet volcanites, as being early Vendian. On this basis the pelitic Deilegga units would correlate with the intertillite Dunderdalen-Chamberlindalen pelites and basites further north as also suggested by Krasil'shchikov \& Kovoleva (1979), the Gashamna phyllites being post-late Varanger tillite.

(iii) Ohta \& Dallmann on the other hand (in their preliminary edition of map B12G, 1992 confirmed 1996), mapped the Gåshamna phyllite as extending northwards into the DunderdalenChamberlindalen pelites, and so it would be earlier than the Kapp Lyell glacials.

It is my opinion that only (a), (b), (c) and (d) above are proto-basement and the remaining Precambrian rocks are mostly Vendian (Table 3 ).

\section{Nathorst Land}

The only possible candidate crops out at the western tip of the Midterhuken peninsula. The marbles there have been correlated with the Magnethøgda Group immediately to the south (Dallmann et al. 1990), and therefore qualify as likely proto-basement. In particular four units of the Magnethøgda sequence are mapped; 50, massive dolomite; 51 , undifferentiated carbonate rocks; 53 , dark phyllite; 55 , quartzite and phyllite.

\section{Nordenskiöld Land}

Harland et al. (1993) made the whole of the preCarboniferous outcrop of Nordenskiöldkysten to be of Varanger (Early Vendian) age with the lower and upper tillites at the bottom (in the south) and top (in the north) of the succession respectively. On this basis no proto-basement is exposed in Nordenskiöld Land.

However, this interpretation conflicts with the Norsk Polarinstitutt maps whose geologists have done most of the survey (Hjelle et al. 1986; Ohta \& Hjelle et al. 1992), and also with Russian authors (e.g. Turchenko et al. 1983). The matter was discussed by Harland et al. (1993). If we were 
Table 3. Approximate correlation of Precambrian strata in southern and western Spitsbergen as proposed here. The filled triangles represent the later (Mortensnes) Varanger glacial deposits and the open triangles the earlier (Smaảlfjorden) Varanger tillites. The Eimfjorden Group in the middle column is as mapped by Czernay et al. (1992) and not as originally defined by Birkenmajer.

\begin{tabular}{|c|c|c|c|c|c|}
\hline & Nordensköldkysten & $\begin{array}{c}\text { N.W. Wedel Jarlsberg } \\
\text { Land }\end{array}$ & $\begin{array}{c}\text { S.W. Wedel Jarisberg } \\
\text { Land }\end{array}$ & $\begin{array}{l}\text { E. Wedel Jarlsberg } \\
\text { Land }\end{array}$ & Sørkapp Land \\
\hline$\frac{0}{\epsilon}$ & & & & $\begin{array}{l}\text { Sorkapp Land Group } \\
\text { Sofiekammen Group }\end{array}$ & $\begin{array}{l}\text { Sørkapp Land Group } \\
\text { Soflekammen Group }\end{array}$ \\
\hline ?Ediacara & 11111111111 & 11111111111111 & & Fannytoppen Fm A & \\
\hline $\begin{array}{c}\text { Late } \\
\text { Varanger } \\
\Delta\end{array}$ & $\begin{array}{l}\text { Kapp Linné Fm } \\
\text { Linnefjella unit }\end{array}$ & $\begin{array}{l}\text { Kapp Lyell Group } \\
\text { Konglomerattjellet Group }\end{array}$ & Aust Torellbreen Group & $\begin{array}{l}\text { Fannypynten Fm } \\
\text { (unexposed unit) }\end{array}$ & \\
\hline $\begin{array}{c}\text { Early } \\
\text { Varanger } \\
\triangle\end{array}$ & $\begin{array}{l}\text { Malmberget unit } \\
\text { Lagneset Fm (B) } \\
\text { Gravsjeen Fm } \triangle \\
\text { Lagnesrabbane Fm }\end{array}$ & $\begin{array}{l}\text { Dunderbukta Fm } \\
\text { Chamberlindalen Fm (B) } \\
\text { Gaimardtoppen Fm } \\
\text { Fiøykalven Fm } \triangle \\
\text { Thlisfiellet Fm }\end{array}$ & $\begin{array}{l}\text { Deilegga fms } \\
\text { Jens Erikfjellet Fm (B) } \\
\text { Elveflya Fm } \triangle\end{array}$ & Hansvika fm $\triangle$ & \\
\hline Sturtian & $\|_{\|}^{\text {Kapp Martin Fm }}$ & $\sim^{?}$ & Kunsodden- & & $\begin{array}{l}\text { Hölerpynten } \mathrm{Fm} \\
\text { Quartzite } \mathrm{Mbr} \\
\text { Oolitic lst Mbr } \\
\text { Wurmbrandegga Mbr } \\
\text { Andvika Mbr } \\
\text { Kviveodden Mbr }\end{array}$ \\
\hline $\begin{array}{l}? \\
\text { Meso- } \\
\text { Protero- } \\
\text { zoic }\end{array}$ & & $\begin{array}{l}\text { Nordbukta Group } \\
\text { Dordalen Fm } \\
\text { Thilsdalen Fm } \\
\text { Trinutane Fm } \\
\text { Seljehaugfjellet Fm } \\
\text { Botnedalen Fm } \\
\text { Peda Kokkfjellet Fm } \\
\text { Evafjellet Fm } \\
\text { Kapp Berg Fm }\end{array}$ & $\begin{array}{l}\text { Eimfjellet Group } \\
\text { Pytthomem Fm } \\
\text { Gulliksenfjellet Fm } \\
\text { Bratteggdalen Fm } \\
\text { Skàljellet Fm } \\
\text { Eimfjellbreane Fm } \\
\text { Skjerstranda Fm } \\
\text { isbjornhamna Group } \\
\text { Revdalen Fm } \\
\text { Ariekammen Fm }\end{array}$ & Magnethøgda Group & Lyngebreen sequence \\
\hline
\end{tabular}

wrong then we must consider separately the two 1:100,000 maps: B10G (Hjelle et al. 1986) and B9G (Ohta et al. 1992). Map B10G shows "tilloid conglomerates" (?unit 10) as Vendian, the rest (units 1-9) being earlier (Late Riphean or middle Late Precambrian) and are correlated mainly with the succession south of Bellsund. Map B9G shows the Kapp Linné diamictite (unit 24) and quartzite metapelites (unit 25) as Vendian and units 28, 29, and 32 as "?Middle Proterozoic". Unit 32 of B9G is the same as units 3 and 4 of B10G. The preVendian units of $\mathrm{B} 9 \mathrm{G}$ are correlated with the St. Jonsfjorden Group north of Isfjorden. We are in approximate agreement as to the correlation north and south of the two large fjords; but the rocks so correlated are all Vendian according to Harland et al. (1993). The difference arises from our interpretation of two (rather than one) Vendian (Varanger) glacial horizons with thick intertillite rock units between them which others have considered as pre-Vendian. However, no stratigraphic major break has been identified in these successions and without a postulated tectogenic episode a case has yet to be made for protobasement.

\section{Oscar II Land}

This interpretation of the rocks of Oscar II Land follows that of Harland et al. (1993) and Table 4 which is based on many years of field work (e.g. Harland et al. 1979 et seq.) resulting in the recognition of two (Varanger) tillite horizons. Thus most of the rocks of Oscar II Land are Vendian comprising the Comfortlessbreen and St. Johnsfjorden groups (Table 3). However, after Ohta et al. (1995) the Aavatsmarkbreen (pelite) Formation is removed from the Comfortlessbreen 
Table 4. Oscar II Land sequence.

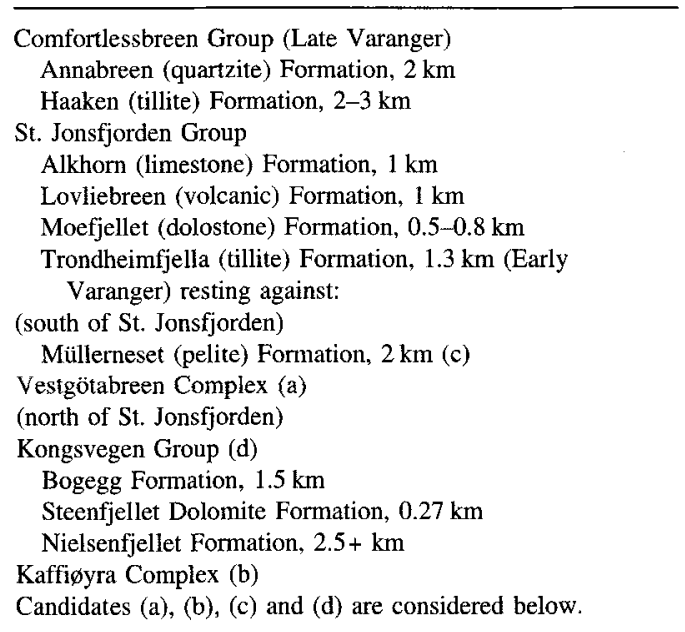

Group as more likely belonging to the (Ordovician) complex south of St. Jonsfjorden.

(a) Vestgötabreen Complex. - These high grade (blue-schist facies) rocks have attracted much attention (e.g. Gee 1966; Horsfield 1972; Ohta 1979; Hirajima et al. 1988) and have been shown to lie unconformably beneath strata of Ordovician and Silurian age (Scrutton et al. 1976; Ohta et al. 1983). Their K-Ar determinations gave 410-484 and $631 \mathrm{Ma}$ (Horsfield, 1972); $453-475 \mathrm{Ma}$ (Dallmeyer et al. 1990); 476, 436 Ma by ${ }^{40} \mathrm{Ar}-{ }^{39} \mathrm{Ar}$ and $2121 \mathrm{Ma}$ by zircon upper intercept and $\mathrm{Sm}-\mathrm{Nd}$ modal ages (Bernard-Griffiths et al. 1993). Ohta et al. (1989) from ${ }^{40} \mathrm{Ar}-{ }^{39} \mathrm{Ar}$ determinations, concluded three Caledonian tectonic events:

(1) Early to Middle Ordovician subduction of oceanic crust;

(2) Caradoc to Wenlock uplift and deposition of flysch;

(3) Late Wenlock folding, thrusting and low grade metamorphism.

The 2121 Ma event remains to be documented; but some tectonic inclusions of proto-basement may be present in a subduction zone.

(b) Kaffiøyra shear zone. - The low ground of Kaffiøyra and Sarsøyra contains a melange including a basement candidate. The complex is now thought to have been sheared in the Paleogene Kaffiøyra strike-slip zone and so extended potential proto-basement north to Sar- søyra in Forlandsundet (Ohta et al. 1995). They regarded the protoliths of the complexes as originating from the basic volcanics of the Løvliebreen Formation. A similar opinion was independently suggested by Harland et al. (1993) for the possibly equivalent Pinkie Complex in Prins Karls Forland. Our view would thus make the protoliths Early Vendian, and the complex deriving therefrom as probably Ordovician and therefore not proto-basement. Others, however, have mapped the Løvliebreen Formation as middle Proterozoic (e.g. Map B8G).

(c) Mullerneset Formation. - This is dominated by pelites and psammites. The boundary with the (Early Varanger) Trondheimfjella Formation (with carbonate clasts), north of Eidembukta and north of the Carboniferous outcrop, appears as a concordant transition (Harland et al. 1993). The higher grade of metamorphism need not imply any tectogenesis between them and so is not regarded as feasible proto-basement.

(d) Kongsvegen Group. - Orvin (1934) described the succession south of $\mathrm{Ny}$-Ålesund to be inverted and so to young northwards. Thus his units 1 to 10 of mainly pelitic schists (later named Nielsenfjellet Formation by Challinor 1967) pass southwards down into the Steenfjellet Dolomite (unit 11) and the Bogegg schists (unit 12) which he depicted as passing conformably down into the "Dolomites and limestones at Forlandsundet". Challinor (1967) followed this opinion naming the last unit his Bjørvigfjellet Formation. C. B. Wilson after reconnaissance of Oscar II Land in $1958 \mathrm{had}$ concluded that the reverse was necessary (before his death in 1959, Harland 1960). After a muddled sequence of opinions and further fieldwork, the conclusion (Table 4) confirms Wilson's first opinion, hence a faulted, conformable transition (Harland in press).

A case thus has to be made for the Kongsvegen Group to be proto-basement even though it appears to be pre-Vendian because it underlies the lower tillite formation (Trondheimfjellet Formation of Harland et al. 1979 and Harland et al. 1993). As of now there is no known evidence to claim this as proto-basement.

However, others have adopted a different stratigraphy in which rocks identified as two tillite horizons have been correlated as one, or the lower one has not been so recognised (e.g. Flood et al. 1971, Hjelle et al. 1979, Hjelle \& Lauritzen 
1982; and Ohta et al. 1992). They thus regarded the intertillite formations as pre-Vendian.

\section{Prins Karls Forland}

The same stratigraphic considerations apply to Prins Karls Forland as to Oscar II Land. The sequence was outlined in Harland et al. (1979) and largely followed by Harland et al. (1993). At the same time alternative interpretations have been put forward by Flood et al. (1971); Hjelle et al. (1979); Hjelle \& Lauritzen (1982). However, the two first-mentioned papers argued a time sequence (Table 5) which was confirmed in part by the Vendian biota in the Scotia Group (Knoll \& Ohta 1988).

Table 5. Prins Karls Forland sequence.

\begin{tabular}{ll}
\hline Grampian Group, $3.6 \mathrm{~km}$ & $\begin{array}{l}\text { (?Silurian-Ordovician) } \\
\text { (Ediacara) }\end{array}$ \\
Peachia Group, 1 km & \\
Geikie Group, $0.77 \mathrm{~km}$ & \\
Ferrier Group 1+ km & (Late Varanger) \\
Pinkie Formation $0.2+\mathrm{km}$ & (?Early Varanger; \\
& ?Ordovician tectonised) \\
\hline
\end{tabular}

Rocks in this island succession have been placed in a Vendian through (probable) Silurian sequence. The Pinkie Formation is of higher metamorphic grade and with faulted contacts (Harland et al. 1979; Hjelle et al. 1979; Manby 1983,1986 ). It is mainly meta-basites with quartzbiotite schist, feldspathic magnetite-biotite schist, sillimanite-garnet-biotite-schist, felsite and calcareous brecciated slate with biotite. Such metavolcanic facies, by analogy with other parts of western Spitsbergen, would probably lie below the upper tillite in the Varanger sequence so the Pinkie Formation could be part of the underlying St. Johnsfjorden Group, but tectonised in the Eidembreen event as was the Vestgötabreen Complex.

\section{Northwestern Spitsbergen}

(a) Krossfjorden Group in Albert I Land and eastern Haakon VII Land. - The areas from Kongsfjorden clockwise to Liefdefjorden are treated as one pre-Devonian, probably Precambrian, terrane, except for the Richarddalen Complex in the Biskayerhuken Peninsula. All igneous and metamorphic rocks in this sector were long considered to be Archean (e.g. Suess 1888; Nathorst 1910) until Holtedahl (1912; 1914) demonstrated that the metamorphism and igneous activity were "Caledonian". This has been confirmed by isotopic age determinations (e.g. Gayer et al. 1966; Hjelle 1979). Generally these ages are mid-Paleozoic.

Precambrian rocks are exposed only to the west of the Breibogen Fault. This is referred to here as the northwestern terrane and is divided by the N-S Raudfjorden Fault into two sub-terranes: Albert I Land and Eastern Haakon II Land.

The crystalline complex of Albert I Land (west of Raudfjorden Fault includes the Hornemanntoppen Batholith (414 Ma by $\mathrm{Rb}-\mathrm{Sr}$ whole rock, Hjelle 1979) and minor granitic bodies. These are intrusive mainly into migmatites $(375-450 \mathrm{Ma}$ by $\mathrm{K}$-Ar, Gayer et al. 1966) which in turn invade and consume the lower rocks of the Krossfjorden Group (Harland 1985) i.e. the Generalfjella, Signehamna and especially the Nissenfjella Formation (Gee \& Hjelle, 1966; Abakumov 1979; Hjelle, 1979). The oldest strata resting on them are early Devonian. The metamorphism of the pre-Devonian and the granitic rocks have been dated isotopically as mid-Paleozoic (e.g. Gayer et al. 1966; Dallmeyer 1989). Balashov et al. (1996) also obtained (Paleozoic) ages from granites by $\mathrm{Rb}-\mathrm{Sr}$ of $412 \pm 4.8 \mathrm{Ma}$ and by Zircon $\mathrm{Pb}$ evaporation method of $412 \pm 56 \mathrm{Ma}$. One zircon $(952 \pm 20 \mathrm{Ma})$ was considered to be inherited.

The pre-Caledonian succession is relatively simple where least altered in the southwest of the sector (Table 6).

The consistent stratal sequence suggests that only one major tectogenesis had been effective. The associated migmatic-magmatic episode may be referred to as Smeerenburgian (Harland) without prejudging its age.

In Eastern Haakon VII Land (between Raudfjorden and Breibogen Faults) there is a metamorphic belt running from Biskayerhuken on the north coast through to Liefdefjorden. South of Liefdefjorden similar rocks extend with the same $\mathrm{N}-\mathrm{S}$ trend beyond Bockfjorden and south to Holtedahlfonna (Gee \& Moody Stuart, 1966; Gjelsvik, 1979).

The sequence north of Liefdefjorden (Table 7) is from D. G. Gee (in Harland 1985): but modified both to extend the Krossfjorden Group and to avoid names already in other use.

Isotopic determinations of these rocks ranged in age from 413 to $553 \mathrm{Ma}$ (Gayer et al. 1966; Dallmeyer, Peucat \& Ohta, 1990). Whereas the extreme ages extend back just to Precambrian 
Table 6. Krossfjorden Group west of Raudfjorden Fault.

\begin{tabular}{|c|c|}
\hline $\begin{array}{l}\text { Generalfjella } \\
\text { Formation: }\end{array}$ & $\begin{array}{l}2 \mathrm{~km} \text {, marble with interbedded pelite and } \\
\text { psammite }\end{array}$ \\
\hline $\begin{array}{l}\text { Signehamna } \\
\text { Formation: }\end{array}$ & $\begin{array}{l}2-2.5 \mathrm{~km} \text {, mainly pellites with psammites and } \\
\text { some quartzites }\end{array}$ \\
\hline $\begin{array}{l}\text { Nissenfjella } \\
\text { Formation: }\end{array}$ & $\begin{array}{l}2-3 \mathrm{~km} \text {, pelites with conformable amphibolite } \\
\text { and some feldspathites (feldspar } \\
\text { porphyroblastic gneiss). These pass } \\
\text { northwards and downwards into } \\
\text { (Smeerenburgfjorden Caledonian gneisses } \\
\text { and migmatites (Abakumov 1979) }\end{array}$ \\
\hline
\end{tabular}

time on current time scales, the body of isotopic data does not suggest a Precambrian tectogenesis.

The Krossfjorden Group strata crop out in simple pattern. The litho-facies in the two subterranes correlate well. The coherence of strata throughout the sector make it unlikely that an earlier deformation significantly disturbed the succession prior to the Caledonian tectogenesis. No positive evidence for proto-basement in Northwestern Spitsbergen is yet available except in the Richarddalen Complex.

(b) Richarddalen Complex. - South of Biskayerhuken, east of Raudfjorden and west of Breibogen is a unit distinct from the above mentioned rocks, and separated from them by thrust faulted contacts. This Richarddalen Complex achieved notice first because of eclogites and other high grade metamorphic rocks (Gee, 1966; Gee \& Hjelle, 1966). Attempts have been made to obtain Precambrian ages. Values were obtained from $\mathrm{U}-\mathrm{Pb}$ on zircons in meta-granites and a gabbro (Peucat et al. 1989; Dallmeyer et al. 1990). It was suggested that these rocks were derived from reworking at $965 \pm 1 \mathrm{Ma}$ of ancient crust "as old as Archaean" ( $3234 \pm 43 \mathrm{Ma}$ ). In turn they were reworked by later tectogenesis with age determinations ranging from 661 to $402 \mathrm{Ma}$ (Ohta, 1992) or $382 \mathrm{Ma}$. It is therefore virtually certain that the Richarddalen Complex is not only Proterozoic (Neoproterozoic) basement but probably in part at least Archean.

These authors commented: "The high degree of discordancy of the zircon data and their typical magmatic habit strongly suggests that the lowerintercept age of $965 \pm 1 \mathrm{Ma}$ corresponds to the crystallisation of zircon from the magmas. The small amount of the ancient radiogenic lead indicates a component of Archean crustal reworking. The age of $3234 \pm 43 \mathrm{Ma}$ can be the mean age of several populations of zircon of different
Table 7. Krossfjorden Group to east of Raudfjorden Fault.

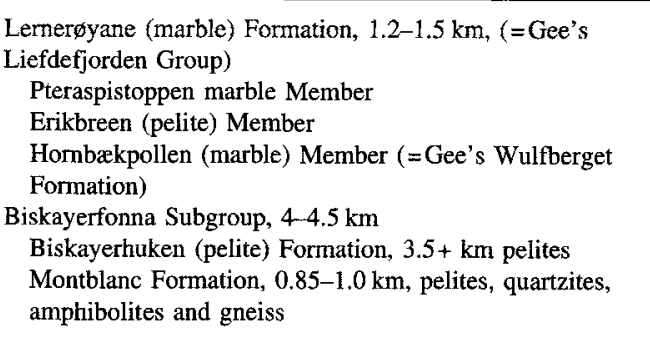

ages but strongly suggests derivation from Archaean crust" (Peucat et al. 1989 p. 278).

Age determinations from eclogite and a "late" intrusion (felsic neosome of agmatite), identify a later (the latest?) Proterozoic event. K-Ar methods on hornblende gave ages between 520 and $541 \mathrm{Ma}$ (Gayer et al. 1966) supported by ${ }^{40} \mathrm{Ar}-{ }^{39} \mathrm{Ar}$ data (Dallmeyer et al. 1990). However zircons from the ecologite by $\mathrm{U}-\mathrm{Pb}(620 \mathrm{Ma})$ suggest a magmatic origin and $620 \pm 2 \mathrm{Ma}$ is suggested for the time of emplacement of the acidic magmas which are younger than the eclogite. The conflicting data nevertheless suggest a tectonothermal event from 660 through 620 to $540 \mathrm{Ma}$ (Peucat et al. 1989), i.e. pre-Vendian ?through Vendian. A $965 \mathrm{Ma}$ magmatic event is established (i.e. proto-basement), with relicts of an earlier proto-basement (somewhere) of Archean age, and a later (latest Proterozoic or Paleozoic) thermal event of unknown significance.

\section{Ny Friesland}

Whereas the candidates considered hitherto are rock units from distinct localities or tectonic settings, the candidates in Ny Friesland have been postulated at different levels in one stratal pile. The strata have been described, discussed and mapped (Harland \& Wilson, 1956; Harland et al. 1966 to Harland et al. 1992) and Table 8 below.

The four candidates for proto-basement to be considered are indicated above as (a), (b), (c) and (d). If the above is a time sequence without tectonic insertion then if (a) is basement so will be (b), (c) and (d) and so on.

From the earliest synthesis (Harland \& Wilson, 1956) to the latest (Harland et al. 1992) it has been said that there is an apparently concordant and consistent sequence throughout Ny Friesland; but that there may well be proto-basement concealed or confused by the intense Caledonian tectogen- 
Table 8. Hecla Hoek sequence (Ny Friesland).

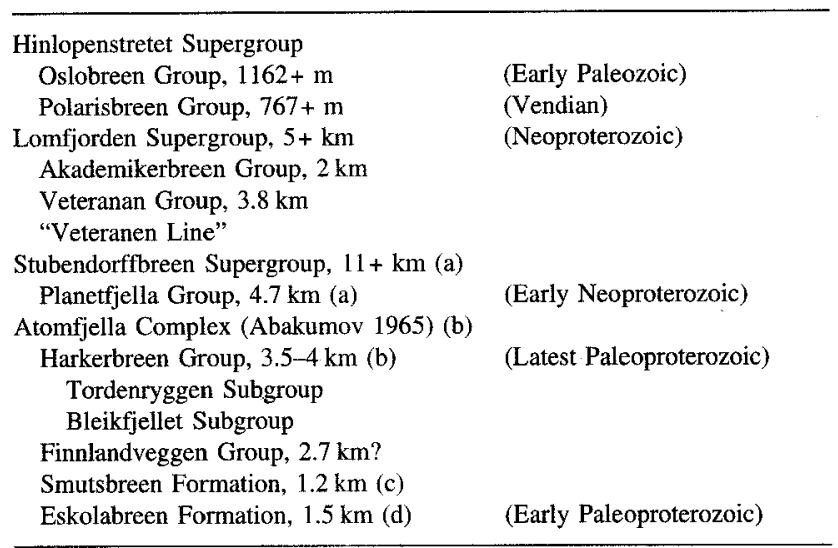

esis. Therefore it is argued that for (a), (b), (c) or (d) to be accepted as proto-basement there is some obligation to demonstrate where in the succession the stratigraphic break or tectonic insertion occurs. The generally available map (Harland et al. 1992) is still only a reconnaissance map based on work concluded about 1965. Using much the same sequence and nomenclature, the map by Johansson et al. (1995) adds new data partly to show the outcrops of the newly defined InstrumentbergetFlaten granitic gneiss, and partly for the improved outcrop pattern of the Harkerbreen Group formations in the remote interior, presumably based on unpublished mapping by Abakumov. All candidate rocks were certainly tectonised in midPaleozoic, mainly Silurian time, (Gayer et al. 1966; Gee \& Page 1994) and the methods of dating were not sufficient, until recently, to demonstrate basement material within the sequence (Gee et al. 1992; Balashov et al. 1993).

Since Harland (1941) it was known that thrust and nappe structure was dominant, that many layers could be thrust slices and that this structure was imparted during the Caledonian Ny Friesland Orogeny (Harland 1959). To reconcile these observations with the consistency of the stratigraphic sequence throughout most of the metamorphic terrane it has been supposed that the lithostratigraphic units were sufficiently thick for the tectonism to affect the detail but not the overall sequence.

Hypotheses (a), (b), (c) and (d) are considered in turn:

Candidate $(a)=$ Stubendorffbreen Supergroup. This is the oldest hypothesis because west of the
Veteranen Line (separating Planetfjella and Veteranen groups) the rocks are conspicuously metamorphosed, whereas generally to the east they are not. So, for example, Nathorst (1910) mapped the Stubendorffbreen Supergroup as Archean and the younger rocks as Hecla Hoek. This distinction persisted (e.g. Tyrrell 1922 and Fairbairn 1933). On the other hand Harland \& Wilson (1956) outlined the first comprehensive sequence and map (Harland 1959; Harland et al. 1966) of Ny Friesland without any major stratigraphic break. In the absence of conflicting evidence this interpretation had since been generally followed until lately. Manby (1990) claimed candidate (a) as basement, stressing the metamorphic contrast along the boundary between the Planetfjella and Veteranen groups. By that date it had already been argued (Harland, 1985) and later by Harland and Manby in Harland et al. (1992) that the Veteranen Line bounded a shear zone as part of the major sinistral Caledonian transpression. In the north, to the east of the line, Vendian strata are metamorphosed. If a sinistral shear zone, traceable for at least $50 \mathrm{~km}$, occupied the vertical strata in a bedding-parallel attitude, it would account for similar stratal sequences across the line both north and south over a distance of about $100 \mathrm{~km}$. Such stratal consistency in outcrop does not suggest a major unconformity even if severely faulted.

However, Gee et al. (1994), marked the Veteranen Line in cross-section with a major dip-slip normal fault separating the whole Stubendorffbreen Supergroup to the west. Gee et al. (1995) went further and argued, from new data from Nordaustlandet that the pre-middle Hecla 
Hoek sequences are so dissimilar that a major "terrane" faulted boundary is necessary along this line. This theme was renewed by Manby \& Lyberis (1995). These contributions ignored earlier mapping with stratigraphic continuity across this line over a length of $100 \mathrm{~km}$, or failed to take into account the effect of a shear zone within a steeply dipping stratigraphic unit. Harland (1995) reminded readers that the original claim for a stratigraphic transition between the Veteranen and Planetfjella groups of Harland \& Wilson (1956) was supported in detail by Wilson (1958) and Wallis (1969). Those observations have not been challenged and a better case needs to be made before accepting candidate (a) as proto-basement or as a terrane significantly distinct from that to the east (see Terrane implications, below).

Candidate $(b)=$ Atomfjella Complex. - Abakumov (1965) and Krasil'shchikov (1965), following the stratigraphy and existing maps of Harland and others, combined the two lower groups as the Atomfjella Complex.

The boundary between the Planetfjella and Harkerbreen groups, although taken as faulted or concordant (e.g. Wallis 1969), is more difficult to determine. Thus, whereas the Bleikfjellet Subgroup could be correlated from south to north on the west of the Atomfjella Arch, the Tordenryggen Subgroup appeared to be largely obscured by ice in middle Ny Friesland. A possible $2.5 \mathrm{~km}$ of Tordenryggen Subgroup could be missing in the north which would give a present $5 \%$ angular unconformity below the Planetfjella schists. This was evident in the map in both Gee et al. (1994) and Johansson et al. (1995) which, without their comment, shows successive truncation northwards of the Sørbreen Formation, and then the Vassfaret Formation, by the Planetfjella Group boundary. It is assumed that this mapping of the localities in remote middle Ny Friesland is from Abakumov's unpublished map (as acknowledged by Johansson et al. (1995)). That the outcrops of Planetfjella and Harkerbreen groups appear sub-parallel may be the result of Silurian compression and transpression, but this would not explain the consistency of the succession of formations if there had been a major angular unconformity as might have resulted from an orogenic episode.

However, repeated attempts to identify protobasement rocks have borne fruit (Gee, 1991; Gee et al. 1992; Johansson 1994; Johansson et al. 1995). Manby \& Lyberis (1991) indicated a preliminary age of $1757 \pm 90 \mathrm{Ma}$ by Sm-Nd and $\mathrm{Rb}-\mathrm{Sr}$ methods from cross-cutting amphibolites. As these rocks would appear to belong to the Harkerbreen Group the evidence would support Candidate (b) though not be inconsistent with Candidate (a). U-Pb results from zircon analyses, have given ages of granitoids around $1750 \mathrm{Ma}$ (Gee, 1991); $1670 \mathrm{Ma}$ and $1778 \mathrm{Ma}$ (Gee et al. 1992). Gavrilenko \& Kamensky (1992) in Balashov et al. (1993) investigated an ultrabasic dyke in the north (Mosselhalvøya) approximately between the Planetfjella Group and the Polhem Formation of the Bleikfjellet Subgroup by K-Ar analysis of $\sim 1.8 \mathrm{Ga}$ for the ultrabasic rocks and $\sim 500 \mathrm{Ma}$ for the adjacent strata.

Gee et al. (1991), accepted that the conformable Early Paleozoic-Late Proterozoic (Hinlopenstretet-Lomfjorden) sequence dates back to 800-900 Ma (Knoll \& Swett, 1985) and overlies a metamorphic complex with foliated granititic rocks. Gee et al. argued that the $1750 \mathrm{Ma}$ granites intruded Early Proterozoic or earlier meta-sediments and that (probably mid-Proterozoic) dolerite dykes cut both granites and their host rocks. Moreover, the gneissic granitoids have tectonic contacts with the underlying rocks and occur in at least two structural levels referred to as thrust intercalations. The thrusting is accepted as Caledonian.

However, Hellmann et al. (1997) obtained Pbevaporation ages of detrital zircons ranging from 1317 to $2710 \mathrm{Ma}$. The younger age is the maximum for deposition of the Polhem Formation. Therefore isotopic evidence does not require a break in the metasedimentary sequence and the authors then reinterpreted the granitoids as slices of basement within the Hecla Hoek sequence.

Candidate $(c)=$ Finnlandveggen Group - - Gee et al. (1994) applied a thrust argument for this Harkerbreen Group-Smutsbreen Formation. contact which is not in question (Harland 1941). As to the stratigraphic position of the Smutsbreen Formation, the facies are altogether distinct with mauve psammites ranging through calc-schists to marbles. Gee \& Page (1994) mapped it with the Rittervatnet and Polhem formations of the Bleikfjellet Subgroup which might suggest stratigraphic continuity. Continuity was also argued by Balashov et al. (1993) and supported by the youngest detrital zircons in the Smutsbreen Formation giving a maximum age of $1190 \mathrm{Ma}$ (Gee \& Hellmann 1996). 
It may be noted here that a serious mistake in preparation of the coloured map by Harland et al. (1992) showed Harkerbreen rocks within the Atomfjella antiform to the south in conflict with all other earlier and later schematic maps.

Candidate $\quad(d)=$ Eskolabreen Formation/ Complex. - If the Finnlandveggen Group contains proto-basement it could be the feldspathic and porphyroblastic rocks of the Eskolabreen Formation. This appeared to be supported by $\mathrm{U}-\mathrm{Pb}$ determinations from south of Stubendorffbreen. Intercepts at $2415 \pm 34$ and $624 \pm 60$ suggested that the Eskolabreen gneisses are earliest Proterozoic, and indeed proto-basement (Balashov et al. 1993). Whereas since (1941) Harland viewed this as potential basement over which the Smutsbreen strata had been thrust, there is an apparent concordance, as was confirmed by Balashov et al. (1993). If this be earliest Proterozoic basement it is not now obvious where above it an unconformity might be. However the latest determinations in these rocks with the widespread c. $1770 \mathrm{Ma}$ ages (Larionov et al. 1995) make such an unconformity feasible, even though within the formation are marble bands showing affinity with the Smutsbreen Formation.

In the light of the above evidence Candidate (b), the Atomfjella Complex must be accepted as proto-basement with the only identified regional unconformity below the Planetfjella Group as argued here. The problem thus transfers to the nature of the c. $1750 \mathrm{Ma}$ event. The magnitude of the Ny Friesland transpression, which could have sheared discordant into concordant structures, has yet to be determined. The thesis of Gee et al. (1994) and Johansson et al. (1995) that the mapped units are thrust units cannot be denied. Gee \& Hellmann (1996) and Hellmann et al. (1997) then argued that the granitoids were not all intrusive, but were basement rocks of age $1750 \mathrm{Ma}$ and included with their overlying metasediments in composite Caledonian thrust units. The original hypothesis of Harland et al. (1966) in which the granitoids (feldspathites) were interbedded meta volcanics could still stand if their $1750 \mathrm{Ma}$ zircons were inherited from a deeper granite of that age. In any case this is not relevant here if, as argued from mapping, the subPlanetfjella Group unconformity is a sufficient break to make all the Atomfjella Complex Protobasement. But the unconformity marks a minor diastrophism rather than a major orogeny.

\section{Nordaustlandet - main outcrops}

The principal Precambrian outcrops of Nordaustlandet lie north of $79^{\circ} 45^{\prime} \mathrm{N}$ and west of $26^{\circ} 30^{\prime} \mathrm{E}$. The area is remote. Extensive ice sheets fragment the coastal outcrops into relatively unconnected exposures. Earlier pioneering reconnaissance by Nordenskiöld (1863, 1866), Nathorst (1910), and especially by Kulling (1934) and Sandford (1926, $1950,1954,1956)$ must be acknowledged.

Combining helicopter field results of Flood et al. (1969), Hjelle (1978a, b), Ohta (1978, 1982, 1985 ) and the $1: 500,000$ map sheets and descriptions 3G (Hjelle \& Lauritzen 1982) and 4G (Lauritzen \& Ohta 1984), and the 1:1 m bedrock map of Svalbard (Winsnes 1988) which was further modified by Gee, Johansson, Ohta et al. (1995), a Precambrian scheme emerges as summarised in Table 9. Kulling's (1934) names (Murchison Bay and Sveanor etc.) have been retained but not his Cape Hansteen Formation which was approximately equivalent to the Botniahalvøya Supergroup combining the Kapp Hansteen and Brennevinsfjorden groups of Flood et al. (1969). Ohta (1982) established that (as in Table 10) the Kapp Hansteen basal conglomerate rests with angular unconformity on the Brennevinsfjorden Group and lower rocks. This was amply confirmed by Gee et al. (1995) and so the Botniahalvøya Supergroup serves no purpose as it contains a major discontinuity, which they named the Botniahalvøya Unconformity and referred to later rocks in the group as post-orogenic.

On stratigraphic-structural grounds the succession, down through the Murchison Bay Supergroup, is relatively continuous. Its relationship with the Kapp Hansteen rocks is obscured, but the strikes are concordant. The Laponiahalvøya granites are now shown to be Precambrian with ages c. 950 (Gee et al. 1995) and c. $1050 \mathrm{Ma}$ (Larionov et al. 1995). However, the Brennevinsfjorden rocks, with their underlying gneisses, are now well established proto-basement pre-c. 1000 Ma though of unknown age.

Further east, especially around Rijpfjorden, a similar succession obtains with the Austfonna Formation passing into strata with a strong igneous component. These pass down into migmatites which occupy large tracts to the east and south of Duvefjorden. The migmatites puzzled Sandford, who speculated that they are Archean basement, as was accepted by Sokolov (1965). Then, with more observations, supported by 
isotopic dating (e.g. Gayer et al. 1966; Ohta 1992), the migmatites were taken as part of the mid-Paleozoic Caledonian Orogeny as was accepted by Flood et al. (1969). Krasil'shchikov (1965) also accepted the Caledonian remobilisation but postulated that the protoliths were Archean. It now appears that the Rijpfjorden granites may be coeval with the Laponiahalvøya granites. Consequently the Duvefjorden Complex to the east is almost certainly proto-basement.

The correlation as early as 1956 (Harland \& Wilson) suggested that the Planetfjella rocks of Ny Friesland were equivalent to the Cape Hansteen rocks with their similar distinctive acid volcanic components. This has been generally followed (e.g. by Gee 1994). An age of about $900 \mathrm{Ma}$ was suggested based on comparative subsidence rates (Harland \& Gayer 1972; Harland et al. 1992). This postulate was consistent with a biostratigraphic age estimate of c. $800 \mathrm{Ma}$ from the overlying Veteranen Group in Ny Friesland (Knoll \& Swett 1985). Therefore there might be no more evidence for the Kapp Hansteen than for the Planetfjella Group to be proto-basement. See hypothesis (a) for Ny Friesland above. An Rb-Sr age of $766 \mathrm{Ma}$ recalculated to $970 \mathrm{Ma}$ by Ohta (1992) from Gorochov et al. (1977) is consistent. It would be consistent with the evidence for the boundary to be conformable in Ny Friesland and unconformable yet approximately concordant in Nordaustlandet.

The K-Ar and Rb-Sr mid- to Early Paleozoic ages predominate throughout almost the whole latitudinal extent of the island and confirm the impression of ubiquitous Caledonian tecto-thermal events. Therefore determinations with higher values are critical (Table 10).

An unconformity is established making the Brennevinsfjorden rocks proto-basement significantly older than c. $960 \mathrm{Ma}$. A 960 to $950 \mathrm{Ma}$ age appears to be consistent with the Kapp Hansteen Group igneous episode. The Kontaktberget granite cuts the quartz porphyries. They might be coeval, or follow shortly on Kapp Hansteen vulcanism and intrusion.

The Kapp Hansteen Group has been correlated with the Planetfjella Group in Ny Friesland which is not yet established as proto-basement. Correlation should take into account the probable strikeslip displacement west of the Veteranen line of at least $50 \mathrm{~km}$. The feldspar-rich Planetfjella schists could be a distal facies of a c. $950 \mathrm{Ma}$ volcanic/ magmatic centre in Nordaustlandet. The reason to make the Veteranen Line a major terrane boundary, i.a. on the grounds that the $950 \mathrm{Ma}$ event is not reflected in Ny Friesland, is rejected.

\section{Eastern Nordaustlandet, Storøya and Kvitфya}

In Nordaustlandet the eastern-most outcrops of Orvin Land (Nordmarka and Sørmarka) and Isispynten (east of Austfonna), together with some small offshore islands are separated from the main coastal outcrops of northern Orvin Land by the glacier Leighbreen (more than $20 \mathrm{~km}$ wide). These outcrops, and those of Storøya and Kvitøya have much in common, and their basic igneous complexes are not matched elsewhere in Svalbard (Hjelle, Ohta \& Winsnes 1978; Ohta 1978).

From the general disposition of relatively flatlying migmatites of intermediate or acid average composition, the basic rocks, also stratiform, would appear to be higher in the sequence. Moreover, structurally and petrographically the basites (layered gabbro with cumulate facies) in Storøya, at least, would be late tectonic. The calcalkali and tholeitic compositions, suggest orogenic development from island arcs in thick continental terrane (Ohta 1978). This would be consistent with a Caledonian forland to the east. Moreover, the migmatisation possibly lower in the succession, while also of uncertain age, retains a ghost stratigraphy (e.g. at Isispynten, Sandford, 1954; Hjelle 1978a) with relict paleosomes which could well be proto-basement, as with the main migmatite outcrops of Orvin Land.

The only available isotopic evidences of age in this eastern-most area are from Storøya where Ohta (1992) quoted a preliminary age of $600 \mathrm{Ma}$ by $\mathrm{K}-\mathrm{Ar}$ whole rock determination and the three early Rb-Sr determinations from Isispynten (415, 358 and 411 of Hamilton \& Sandford 1964). The two ages 373 and $378 \mathrm{Ma}$ in the northeast corner of Nordaustlandet are misplaced on the maps of Gayer et al. (1966) and Ohta (1992). They belong to granites from the middle of Nordaustlandet determined by Rb-Sr (Hamilton \& Sandford 1964).

A conclusion on these rocks must await further determinations in the light of the probability that all the granites and migmatites of eastern Nordaustlandet with a Caledonian imprint are proto-basement. If so then still earlier basement would form the paleosomes in the migmatites (e.g. Hjelle 1978a). 
Table 9. Compilation of Nordaustlandet succession and correlation with Ny Friesland. The numbers refer to the sources as listed here: (1-2) Nordenskiöld in Kulling 1934; (3) Harland \& Wilson 1956; (4) Abakumov 1965; (5) Harland et al. 1966; (6) Krasil'shchikov 1967; (7) Flood et al. 1969; (8) Ohta 1982; (9) Lauritzen \& Ohta 1984; (10) Gramberg et al. 1990; (11) Gee et al. 1995; (12) Johansson et al. 1995; (13) Larionov et al. 1995; (14) Gee \& Hellmann 1996; (15) Hellmann et al. 1997. Thicknesses are in metres; isotopic ages $\mathrm{Ma}$ in rectangles. The asterisks identify maximum detrital zircon ages and so denote maximum sedimentary ages for the rock.

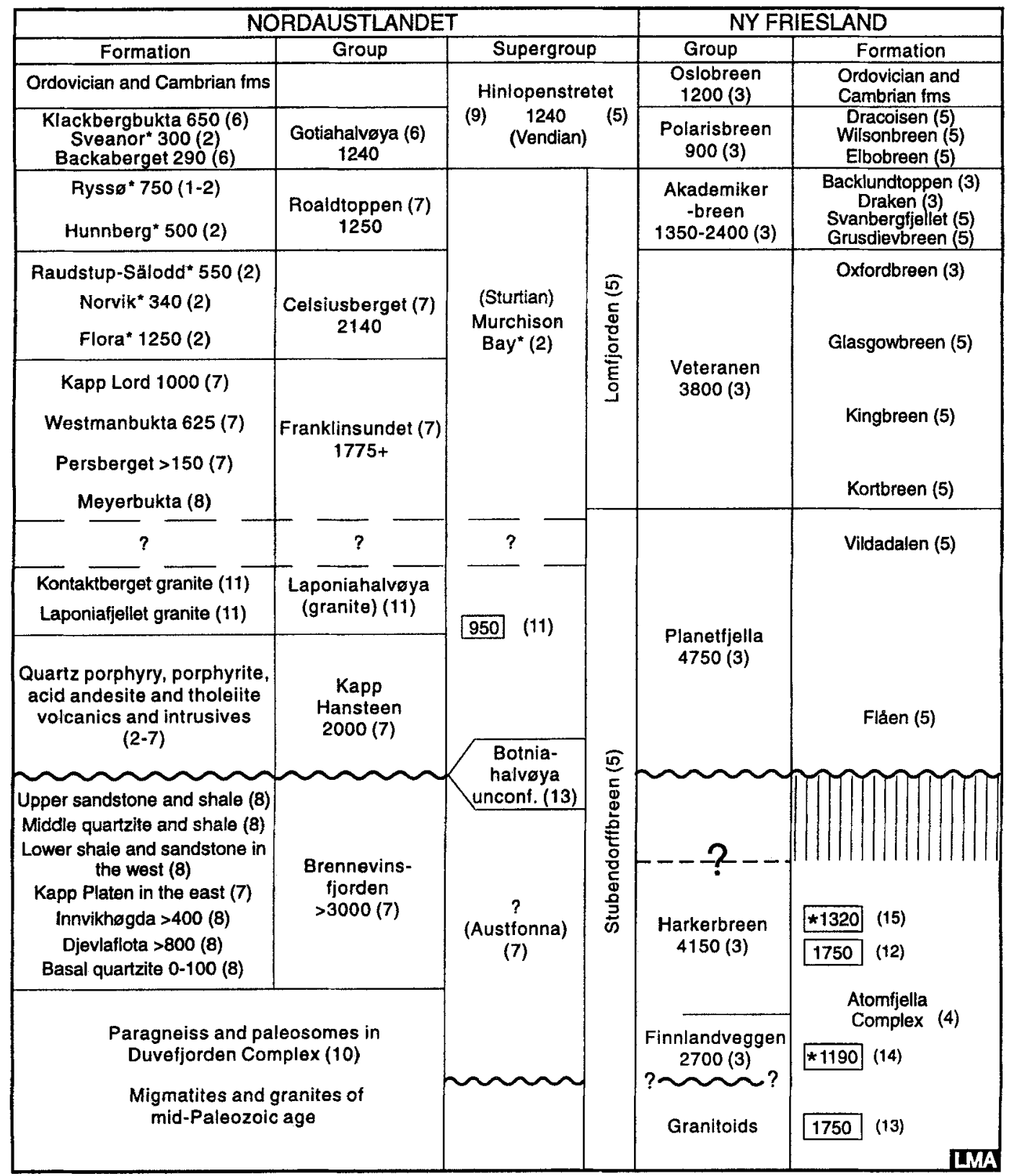

Conclusions as to most likely protobasement

Krasil'shchikov (1979) distinguished two complexes each corresponding to a major development of the archipelago. His older complex, the basement to the Caledonian geosynclinal belt, was regarded as "Lower-Middle" (?) Proterozoic (older than $1650 \mathrm{~m} . \mathrm{y}$.). In this he included the pre-Kapp Hansteen rocks of Nordaustlandet, the Atomfjella Complex of Ny Friesland and the Isbjørnhamna Groups of "middle-upper Protero- 
Table 10. Potential proto-basement isotopic ages in Nordaustlandet.

(i) $1275 \mathrm{Ma}$ was recorded from Aldousbreen (northeastern Wahlenbergfjorden) by $\mathrm{K}$-Ar on whole-rock (Edwards \& Taylor 1976), but this was from an exotic granitoid boulder in a Vendian tillite indicating erosion of proto-basement somewhere, probably but not necessarily in Svalbard.

(ii) Botniahalvøya has yielded a whole-rock K-Ar determination of $766 \mathrm{Ma}$ and another of $970 \mathrm{Ma}$, assuming normal crustal strontium initial ratio, recorded by (Gorochov et al. 1977). These determinations were from the quartz porphyries, intruded probably in Kapp Hansteen Group time, and might indicate proto-basement. Southeastern Rijpfjorden rocks, from Rb-Sr on biotite yielded $618 \mathrm{Ma}$ and on muscovite yielded $636 \mathrm{Ma}$ (Hamilton \& Sandford, 1964). Both values almost certainly derive from the Botniahalvøya Group and may well result from a Caledonian imprint.

(iii) Johansson (1994) reported U-Pb zircon ages of $939 \mathrm{Ma}$ for the undeformed Kontaktberget granite and $961 \mathrm{Ma}$ for the porphyroblastic and gneissic Laponiahalvøya granite. Gee et al. (1995) gave details of these and other determinations and concluded values of $\sim 950 \mathrm{Ma}$ for this intrusive phase. The Kontaktberget granite certainly cuts the Brennevinsfjorden Complex and may cut some basal Kapp Hansteen Group rocks. The Laponiahalvøya granite was previously assumed to be a "Caledonian" batholith. The age of the other batholiths to the east, all associated with earlier migmatites, must now be Proterozoic.

(iv) Gee, Johansson, Ohta et al. (1995) confirmed the above results with full details and mentioned other work by Larionov, identifying a ${ }^{207} \mathrm{~Pb}^{206} \mathrm{~Pb}$ zircon age for such a paleosome of c. $1600 \mathrm{Ma}$ similar to material obtained from the detrital Brennevinsforden zircons.

(v) Nordre Repøya, the island off the middle north coast of Nordaustlandet, has yielded preliminary values of $600 \mathrm{Ma}$ by whole-rock Rb-Sr method, as reported by Lauritzen \& Ohta (1984). Hamilton \& Sandford (1964) reported Rb-Sr ages of 581 to $636 \mathrm{Ma}$ from inner Duvefjorden to the southwest. The metamorphism could be Vendian or, more probably, an earlier event partially altered later.

(vi) The Rijpfjorden granites are analogous to those of Laponiahalvøya. Their ages might thus be expected to be revised from Caledonian to Grenvillian. This was confirmed (Gee \& Teben’kov 1996).

zoic" age. These opinions are not inconsistent with conclusions in this paper except for his chronometric boundary values. However, his upper complex would correspond to what has been referred to as Grenvillian, and include the Kapp Hansteen and related granites.

A major revision of opinion has been taking place regarding the age of the granites and migmatites of Nordaustlandet. Hitherto determinations, reflecting widespread Caledonian activity, have been taken at face value. Zircon ages now suggest that the Caledonian event may have been a rejuvenation of extensive magmatisation around $950 \mathrm{Ma}$. This was not suspected because the surviving (Precambrian) strata did not suggest more than one distinct deformation phase. On this basis the earlier melting event would have taken place in an extensional rather than a compressional regime. The peculiarity of Svalbard history may need interpretation beyond familiar paradigms. Ignoring such speculation, the author's tentative conclusions are listed in Table 11.

\section{Correlation of proto-basement}

If plotted according to age regardless of original proximity, as by Ohta (1992), the evidence illustrates the following pattern:
(1) There is widespread evidence of Early Paleozoic (Caledonian) tectonothermal activity.

(2) No major sub-Cambrian Jarlsbergian event has yet been established. Thus most Late Proterozoic sequences pass into Early $\mathrm{Pa}^{-}$ leozoic strata with some hiatus and minor discordance.

(3) A number of enigmatic Late Proterozoic age determinations (570 to 600 ) have been recorded. These may be the result of Caledonian reworking of older rocks. However, if these data signify Vendian or near Vendian tectonism that would conflict with relatively undisturbed sedimentation in both Ny Friesland and Nordaustlandet.

(4) Values around 950 to $970 \mathrm{Ma}$ are well established at Isbjørnhamna, south of Biskayerhuken and in Nordaustlandet indicating magmatic but, in Nordaustlandet at least, not necessarily orogenic episodes.

(5) The Botniahalvøya orogenic episode deforming the Brennevinsfjorden rocks was earlier than the $950 \mathrm{Ma}$ events by unknown duration.

(6) The Isbjørnhamna and Eimfjellet groups gave a magmatic age of $1130-1135$ to $1200 \mathrm{Ma}$.

(7) Good zircon age estimates of c. $1750 \mathrm{Ma}$ come from $\mathrm{Ny}$ Friesland. It may be added 
that a tentative paleosome age within the Nordaustlandet migmatites of $1600 \mathrm{Ma}$ has been suggested.

(8) A value of $2121 \mathrm{Ma}$, yet to be documented, may date a component in the Vestgötabreen Complex.

(9) A part of the Eskolabreen Formation may inherit a Paleoproterozoic basement at 2415 Ma.

(10) Zircon ages around $3234 \mathrm{Ma}$ imply an Archean component in the Richarddalen Complex.

Ohta (1992) correlated some tectonothermal events thus: (4), (5) and (6) as Grenvillian; (7) as Svecokarelian; (8) as Ladogan, Belomorian; and (9) as Saamian.

It is tempting to describe Svalbard history in terms of orogenic episodes elsewhere; but if in cratons possibly then distant there are reasons for caution: (i) We should be wary of assumptions of global or regional synchroneity by a species of circular logic. The opportunity may then be lost to test synchroneity as a hypothesis. There is a common tendency to employ a nomenclature or terminology which embodies a prejudice in what purports to be an objective description; (ii) Isotopic ages have some degree of precision so that information is lost by lumping into named events of long duration, as for example Grenvillian if defined as 950 to $1250 \mathrm{Ma}$ (Ohta 1992). A span of 300 Myr could well include two or three major tectonic events and might even exclude the value obtained of $930 \mathrm{Ma}$. A duration of only $40 \mathrm{Myr}$ might separate the Eidembreen (mid-Ordovician) event (M'Clintock Orogeny of Trettin 1987) from the Ny Friesland (mid-Silurian) Orogeny; (iii) Isotopic data are expressed in one or other of the international chronometric and chronostratic time scales. Tectonic episodes have also to do with space. The spatial connexion (e.g. Caledonide) may be the conclusion of the research and so should not be assumed in expressing age data (as Caledonian).

\section{Terrane implications}

\section{Contribution of new Precambrian ages}

Improved methods for the investigation of protobasement have renewed thinking on Precambrian relationships of terranes in Svalbard. Some authors have speculated on terrane implications in papers detailing new data (e.g. Peucat et al. 1989;
Dallmayer 1989; Gee et al. 1992; Gee et al. 1995; Gee \& Page 1994). Other papers, without detailing new data, have treated terranes, their boundaries and pre-existing relationships, from the newly emerging evidence of Precambrian thermal events (Gee 1986; Gee 1989; Ohta \& Dallmayer 1986; Ohta et al. 1989; Ohta et al. 1991; Gee et al. 1993; Ohta 1994; Gee et al. 1994; Gee 1994; Manby \& Lyberis 1995). With so much speculation the terrane implications of proto-basement must be addressed. The conclusions arrived here test the original composite terrane concept for Svalbard referred to as "a three provinces hypothesis".

\section{A three provinces hypothesis}

Harland \& Wright (1979) used a range of Phanerozoic as well as later Proterozoic data to develop a hypothesis in which the various terranes of Svalbard (terranes here having a purely descriptive use) could be grouped by the similarities and differences of their history so as to have affinity with three main provinces of Laurentia from which they became detached. Then by sinistral strike-slip displacement and transpression they were joined together in pre-Carboniferous time to form the present composite Svalbard (e.g. Harland 1965, 1966, 1969, 1972, 1973, 1985; Harland \& Wright 1979; Harland \& Gayer 1972; Harland et al. 1974; Harland et al. 1992; Harland, Hambrey \& Waddams 1993). This three province hypothesis was argued on distinct Devonian, Silurian, Ordovician, Cambrian and Vendian data. The pre-Vendian data, even now, hardly provide stronger evidence than do any of the succeeding intervals. However, the subject of this paper is effectively pre-Vendian, therefore, avoiding other discussion here of the validity of the three provinces hypothesis, only the impact of the above conclusions on proto-basement in Svalbard is considered. In brief the three provinces hypothesis groups terranes (and subterranes) thus:

Central East Greenland Province $=$ Svalbard eastern terranes (east of Billefjorden Fault Zone)

North East Greenland-Province = Svalbard central terranes (including NW Svalbard and Hornsund east of Hansbreen)

North Greenland-Pearya Province $=$ Svalbard western terranes (south of Kongsfjorden)

These three groupings of terranes are shown on the diagrammatic map (Fig. 2). The provinces are 


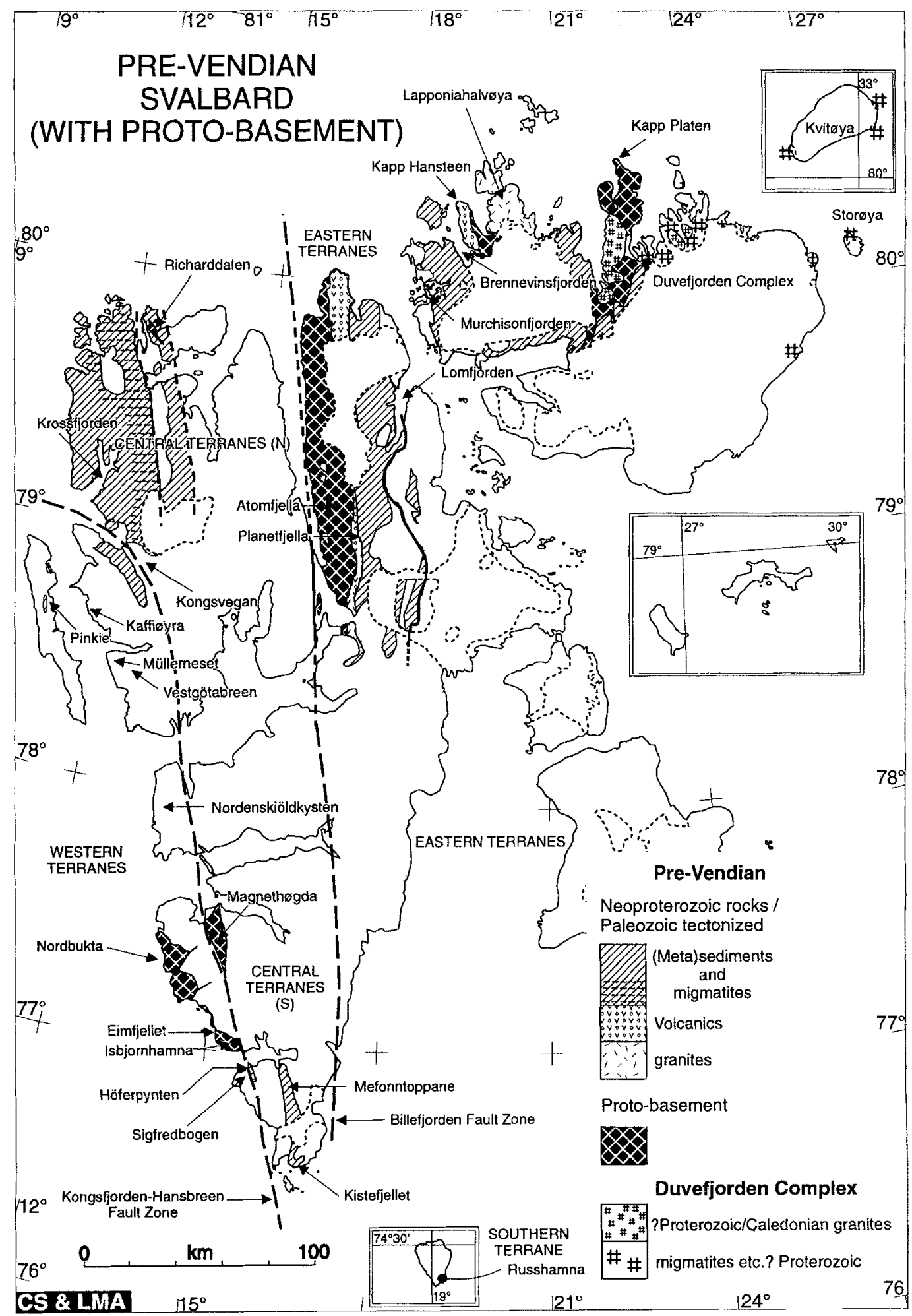


Table 11. Summary of conclusions on candidates.

\section{Mefonntoppane and Kistefjellet rocks} Sigfredbogen

Isbjørnhamna Group, and overlying Eimfjellet Group Nordbukta Group

Magnethøgda Group (and in Nathorst Land)

Vestgötabreen Complex

Kaffiøyra Complex Kongsvegen Group

Krossfjorden Group

Richarddalen Complex

Atomfjella Complex

Planetfjella Group

Kontaktberget and Lapponiafjellet granites

Kapp Hansteen Group

Brennevinsfjorden Group

Eastern granites and Duvefjorden Complex

\section{Sørkapp Land}

Series candidates for proto-basement but on balance considered unlikely.

This unit of small outcrop and unrelated stratigraphy remains as a candidate. It had indeed been treated as basement with Deilegga rocks. In spite of its greater degree of tectonisation a case has yet to be made.

\section{Wedel Jarlsberg Land}

Certainly proto-basement. Ages range between $565 \mathrm{Ma}(\mathrm{K}-\mathrm{Ar})$ and $930 \mathrm{Ma}(\mathrm{Rb}-\mathrm{Sr}$ and $\mathrm{U}-\mathrm{Pb}$ lower intercept). $1200 \mathrm{Ma}$ and $2500 \mathrm{Ma}$ ages are recorded.

Certainly pre-Vendian proto-basement but no further age is available.

A good candidate for proto-basement. The gneisses contrast markedly in tectonic facies from other postulated Vendian rocks whether $5 \mathrm{~km}$ to the west or along strike to the south.

\section{Oscar II Land}

An Ordovician blue-schist assemblage possibly containing melange blocks of Paleoproterozoic basement (2121 Ma) and probably with $1.1 \mathrm{Ga}$ "volcanic rocks" (Ohta private communication). The main complex may be no older than Vendian.

As above.

Some may regard this group as proto-basement. The internal stratigraphy and structure has yet to be resolved. In the meantime a case for the whole or part of the group to be proto-basement remains to be formulated. Harland, Hambrey \& Waddams (1993) suggested, and accepted, here that the upper stratigraphic contact may be concordant.

\section{Northwest Spitsbergen}

Has been subject to a major Caledonian tectonothermal event. Evidence of proto-basement remains to be formulated.

Certainly allochthonous proto-basement. An Archean component (3234 Ma) was reworked at around $965 \mathrm{Ma}$ as well as in Early Paleozoic time.

\section{Ny Friesland}

[The whole complex] lies with (minor angular) unconformity below the Planetfjella Group and is Late Mesoproterozoic proto-basement within which are feldspathic units yielding zircons (c. $1750 \mathrm{Ma}$ ) which might be earlier basement, all in Caledonian thrust structures.

Has been claimed by more than one recent author to be proto-basement. This author considers that no sufficient case has been made.

\section{Nordaustlandet}

These granites, and the somewhat earlier migmatites, have been established as forming at around $950 \mathrm{Ma}$. This might indicate that all the granites and migmatites of Nordaustlandet were basement at least up to the base of the Murchison Bay Supergroup.

Predominantly acid volcanics could be of approximately the same age and overlies the Brennevinsfjorden Group unconformably. Its relationship to the overlying Murchison Bay Super Group is uncertain. It could represent an early volcanic episode followed unconformably but without tectonism by the Murchison Bay strata as seemed to be the case with the analogous succession from acid volcanic Planetfjella Group to Veteranen Group in Ny Friesland. An obscured unconformity has been suggested to separate them.

Certainly proto-basement. Its deformation was earlier than around 960-970 Ma. It may correlate with rocks further east.

Probably comprise the oldest rocks in Nordaustlandet and are probably proto-basement being most likely correlated with the Harkerbreen Group zircons of Ny Friesland on the basis both of acid and basic volcanogenic strata and of the tentative age of $1600 \mathrm{Ma}$.

Fig. 2. Pre-Vendian outcrops are plotted to exclude those in Figure 1. Within these the most likely proto-basement is distinguished in cross-hatched black to which may be added the Duvefjorden Complex. The map plots the Billefjorden Fault Zone and the postulated Kongsbreen-Hansbreen Fault Zone which delineate the Eastern, Central and Western terranes as discussed in the text under Terrane implications. 
postulated to have obtained in Late Proterozoic and separated in Silurian and Devonian time.

Central East Greenland Province. - On the above hypothesis Eastern Svalbard was part of the Central East Greenland Province. It may therefore be interesting to list isotopic ages without qualification, from the Central Metamorphic Complex as mapped by Henriksen \& Higgins (1976, figs. $195 \&$ \& 198), approximately between latitudes 70 and $72^{\circ}$ from north to south (all in Ma): Charcot Land; 411, 417, 632, 1620, 1760 , 1870; north of Nordvestfjorden; $360,373,382$, $395,417,420,423,426,450,474,492,616,738$, 950, 1154, 2345; Hinks Land; 378, 427, 430, 462, 469; 3000; Roysten Nunatakker; 445; Renland; 425, 428, 437; Western Milne Land; 445-460, 950, 1060, 1315, 1490, 1650; East of Rødefjord; 442, 900; Paul Stern Land; 1162; South of Vestfjorden; 406, 616, 1162, 1162; Further south the Ketelidian orogeny at c. 1750 could be reflected in the Ny Friesland event. It would be unwise to apply particular values without reference to field and laboratory data or to later work; but there need be no inconsistency in placing the Svalbard eastern terranes with the Central East Greenland Province where an extension eastwards of the Rinkian terrane of Central West Greenland was subject to possibly "Grenvillian" and certainly Caledonian reworking.

North Greenland-Pearya Province. - At the other extreme: from the Pearya Terrane of northern Ellesmere Island, the only Precambrian age quoted is $965 \mathrm{Ma}$ (Trettin et al. 1992) and $950 \mathrm{Ma}$ is a value obtained for the Eimfjellet and Isbjørnhamna rocks (Johansson 1994). North Greenland, north of Independence Fjord, 799 and $982 \mathrm{Ma}$ are recorded (Escher \& Watt 1976 p. 231). Otherwise there is relatively little age information from the limited outcrop of Precambrian basement, presumably mostly obscured by ice south of the North Greenland Fold Belt. The so-called Carolinidian tectonism of North East to Northern Greenland has been suggested as an 1100 Ma event (Henriksen \& Higgins 1976) but there is little evidence for this event, first suggested by J. Haller in 1961 and refuted by Jepsen \& Kalsbeek in 1985 (Kalsbeek et al. 1993 p. 176). It might be concluded that of the many Precambrian tectonothermal events the $\sim 950 \mathrm{Ma}$ age, though of great interest in itself for the evolution of Svalbard, hardly serves yet to distinguish between Svalbard terranes.

North East Greenland Province. - The intermediate Province of North East Greenland continues the Caledonian terrane northwards but the ice cover is more extensive and largely obscures any northward extension of the Central Metamorphic Complex. Age determinations from the same source (Escher \& Watt 1976) are too few to make useful comparisons. At Danmarkshavn ages of 320 to 380 and $3000 \mathrm{Ma}$ and at Lambert Land $450 \mathrm{Ma}$ were noted (p. 242).

Kalsbeek (1981) from a study in south Greenland concluded that probably most of Greenland, except perhaps the Ketelidian belt, is underlain by Archean rocks, but north of the evident Archean block in south Greenland, later metamorphism has generally so upset the $\mathrm{Rb}-\mathrm{Sr}$ isotope system that $\mathrm{Rb}-\mathrm{Sr}$ whole rock ages cannot give precise ages. Taylor et al. (1992) contra Peucat et al. (1985) came to a similar conclusion to account for anomalously low $\mathrm{Pb}-\mathrm{Pb}$ ages through loss of uranium by later metamorphism.

However, while confirming the existence of Archean basement (e.g. at Danmarkshavn), Kalsbeek et al. (1993) concluded from Rb-Sr, Sm-Nd and zircon U-Pb data that extending for $900 \mathrm{~km}$ along the Caledonian belt from Central East Greenland to North East Greenland is a major province of Proterozoic gneisses formed before $1975 \mathrm{Ma}$, and probably at about $2000 \mathrm{Ma}$, with evidence of rejuvenation of zircon at about $400 \mathrm{Ma}$ around the Silurian Devonian boundary; also the Paleoproterozoic rocks incorporated some Archean material. North of $76^{\circ}$ however there is a lack of a supracrustal record. South of $74^{\circ}$ "Grenvillian" activity is well documented.

In so far as the northward extension of a Grenvillian belt has been postulated (e.g. Gee 1989; Gee et al. 1992) it would be sub-parallel to the Caledonian belt and so would not necessarily overlap it to the east. Indeed, a lack of $950 \mathrm{Ma}$ determinations in Greenland is irrelevant to the palinspastic position of Svalbard terranes which is best argued on post-Grenvillian evidence and may then elucidate the Grenvillian story.

\section{Conclusion}

Ages around $950 \mathrm{Ma}$, described as Grenvillian, have been employed to distinguish, or to unite, terranes. All three provinces in Svalbard contain 
such ages as do at least two of the three provinces in Greenland and Ellesmere Island. The distinction has been made within the Eastern Province that well attested $950 \mathrm{Ma}$ values have been recorded in Nordaustlandet but not in Ny Friesland. However the correlation between the Planetfjella and Kapp Hansteen groups, long claimed and not yet dismissed, would invalidate this contrast. A tentative claim for the $1750 \mathrm{Ma}$ well-attested ages to distinguish Ny Friesland from Nordaustlandet awaits confirmation or otherwise of the tentative age of 1600 from a migmatite paleosome (Gee et al. 1995).

For ages less than $950 \mathrm{Ma}$ there is a scatter of Precambrian values (i.e. $>544 \mathrm{Ma}$, Bowring et al. 1993) without identifying a clear tectonothermal event. A common view is that Caledonian overprinting of older rocks is the cause.

For ages more than $950 \mathrm{Ma}$ it might be argued that the $1750 \mathrm{Ma}$ value from $\mathrm{Ny}$ Friesland and possibly from the Nordaustlandet fit best with the Central East Greenland and Rinkian Province. Greater ages are too few and scattered to have much value in characterising terranes.

Acknowledgements. - I am greatly indebted to Y. Ohta for a detailed criticism of my first [and revised] submission which led to correction of some embarrassing mistakes and the awareness of newly available information. Discussion with D. G. Gee and provision of copies of papers in press has helped to clarify thinking. S. Moorbath advised on isotopic dating of basement.

\section{References}

Abakumov, S. A. 1965: Otlozheniya Nizhney Gruppy Kompleksa Gekla-khuk Na Poluostrove Ny-Frisland (The Lower Hecla Hoek rocks of Ny Friesland Peninsula). Pp. 93-101 in Sokolov, V. N. (ed.): Materialy po Geologii Shpitsbergena (Materials on the geology of Spitsbergen). Leningrad: NIIGA (in Russian).

Abakumov, S. A. 1979: Peculiar features of regional metamorphism of northwestern Spitsbergen. In Winsnes T. S. (ed.): The geological development of Svalbard during the Precambrian, Lower Palaeozoic, and Devonian. Symposium on Svalbard's geology. Oslo, 2-5 June, 1975. Norsk Polarinst. Skr. 167, 29-36.

Balashov, Yu. A., Larionov, A. N., Gannibal L. F., Sirotkin, A. N., Teben'kov, A. M., Ryüngenen, G. I. \& Ohta, Y. 1993: An Early Proterozoic U-Pb zircon age from an Eskolabreen Formation gneiss in southern $\mathrm{Ny}$ Friesland, Spitsbergen. Polar Res. 12(2), 147-152.

Balashov, Yu. A., Teben'kov, A. M., Ohta, Y., Larionov, A. N., Sirotkin, A. N., Gannibal, L. F. \& Ryüngenen, G. I. 1995: Grenvillian U-Pb zircon ages of quartz porphry and rhyolite clasts in a metaconglomerate at Vimsodden, southwestern Spitsbergen. Polar Res. 14(3), 291-302.

Balashov, Yu. A., Peucat, J. J., Teben'kov, A. M., Ohta, Y., Larionov, A. N. \& Sirotkin, A. N. 1996a: Additional Rb-Sr and single grain zircon dating of the granitoid rocks from Albert I Land, northwest Spitsbergen. Polar Res. 15(2), 153-165.

Balashov, Yu. A., Peucat, J. J., Teben'kov, A. M., Ohta, Y., Larionov, A. N., Sirotkin, A. N. \& Bjomerud, M. 1996b: Rb$\mathrm{Sr}$ whole rock and $\mathrm{U}-\mathrm{Pb}$ zircon datings of the graniticgabbroic rocks from the Skålfjellet Subgroup, southwest Spitsbergen. Polar Res. 15(2), 167-181.

Bernard-Griffiths, J., Peucat, J. J. \& Ohta, Y. 1993: Age and nature of protoliths in the Caledonian blue schist-eclogite complex of western Spitsbergen: A combined approach using U-Pb, Sm-Nd and REE whole rock system. Lithos 30, 81-90.

Birkenmajer, K. 1958: Preliminary report on the stratigraphy of the Hecla Hoek Formation in Wedel Jarlsberg Land, Vestspitsbergen. Bul. Acad. Polon. Sci. Sér. Sci. Chim. Géol. Géogra. 6(2), 143-150.

Birkenmajer, K. 1959: Report on the geological investigations of the Hornsund area, Vestspitsbergen in 1958. Part I. The Hecla Hoek Formation. Bul. Acad. Polon. Sci. Sér. Sci. Chim., Géol. Géogra. 7(2), 129-136.

Birkenmajer, K. 1975: Caledonides of Svalbard and plate tectonics. Bul. Geol. Soc. Den. 24(1-2), 1-19.

Birkenmajer, K. 1990: Geology of the Hornsund area. Scale $1: 75,000$. University of Silesia, Katowice, $(+42 \mathrm{pp}$. of explanatory notes)

Birkenmajer, K. 1991: The Jarlsbergian unconformity (Proterozoic/Cambrian boundary) and the problem of Varangian tillites in south Spitsbergen. Polish Polar Res. 12(3), $269-278$.

Birkenmajer, K. 1992: Precambrian succession at Hornsund, South Spitsbergen: a lithostratigraphic guide. Studia Geol. Pol. XCVIII $(X V), 7-66$.

Birkenmajer, K. 1993a: Redefinition of parts of the Vimsodden Subgroup and the Deilegga Group (Proterozoic), SE Wedel Jarlsberg Land, Spitsbergen. Bul. Pol. Acad. Sci. 4l, 137-159.

Birkenmajer, K. 1993b: Some current geological problems in the Precambrian and Lower Palaeozoic of Sørkapp Land, South Spitsbergen. Zesz. Naukowe Uniw. Jagiell. 94, 29-37.

Bjørnerud, M. 1990; An Upper Proterozoic unconformity in northern Wedel Jarlsberg Land, southwest Spitsbergen: lithostratigraphy and tectonic implications, Polar Res. 8(2), $127-139$.

Bjørnerud, M., Craddock, C. \& Wills, C. J. 1990: A major late Proterozoic tectonic event in southwestern Spitsbergen. Precambrian Res. 48, 157-165.

Bowring, S. A., Grotzinger, J. P., Isachsen, C. E., Knoll, A. H:, Pelechaty, S. M. \& Kokolov, P. 1993: Calibrating rates of Early Cambrian evolution. Sci. 261, 1293-1298.

Challinor, A. 1967: The structure of Brøggerhalvøya, Spitsbergen. Geol. Mag. 104, 322-336.

Czerny, J., Kieres, A., Manecki, M. \& Rajchel, J. 1992 : Geological map of the SW part of Wedel Jarlsberg Land, Spitsbergen. Scale 1:25,000. Institute of Geology and Mineral Deposits, University of Mining and Metallurgy, Crakow.

Dallmann, W. K., Hjelle, A., Ohta, Y., Salvigsen, O., Maher, H., Bjørnerud, M., Hauser, E. \& Craddock, C. 1990: Geological Map of Svalbard, 1:100,000, Sheet B11G. Van Keulenfjorden. Norsk Polarinst. Temakart 15 (+58 pp.).

Dallmann, W. K., Birkenmajer, K., Hjelle, A., Mørk, A., Ohta, Y., Salvigsen, O. \& Winsnes, T. S. 1993: Geological Map of Svalbard, 1:100,000, Sheet C13G Sørkapp, with descrip- 
tion). Norsk Polarinstit. Temakart 17 (Map compiled by Winsnes, T. S., Birkenmajer, K., Dallmann, W. K., Hjelle, A. \& Salvigsen, O.).

Dallmeyer, R. D. 1989: Partial thermal resetting of ${ }^{40} \mathrm{Ar} /{ }^{39} \mathrm{Ar}$ mineral ages in western Spitsbergen, Svalbard: possible evidence for Tertiary metamorphism. Geol. Mag. 126(5), 587-593.

Dallmeyer, R. D., Peucat, J. J., Hirajima, T. \& Ohta, Y. 1990: Tectonothermal chronology within a blueschist-eclogite complex, west-central Spitsbergen, Svalbard: evidence from ${ }^{40} \mathrm{Ar}{ }^{39} \mathrm{Ar}$ and $\mathrm{Rb}-\mathrm{Sr}$ mineral ages. Lithos 24(4), 291-304.

Dallmeyer, R. D., Peucat, J. J. \& Ohta, Y. 1990: Tectonothermal evolution of contrasting metamorphic complexes in northwest Spitsbergen (Biskayerhalvøya): evidence from ${ }^{40} \mathrm{Ar} /{ }^{39} \mathrm{Ar}$ and $\mathrm{Rb}-\mathrm{Sr}$ mineral ages. Bul. Geol. Soc. Am. $102,653-663$.

Edwards, M. B. \& Taylor, P. N. 1976: A Rb-Sr age for granitegneiss clasts from the late Precambrian Sveanor Formation, Central Nordaustlandet. Norsk Polarinst. Årbok 1974, 255-258.

Escher, A. \& Watt, W. S. 1976: Geology of Greenland. Geological Survey of Greenland, Copenhagen. $603 \mathrm{pp}$

Fairbairn, P. E. 1933: The petrology of the Hecla Hoek Formation in central Spitsbergen. Geol. Mag. 70, 437-454.

Flood, B., Gee, D. G., Hjelle, A., Siggerud, T. \& Winsnes, T. 1969: The geology of Nordaustlandet, northern and central parts. Norsk Polarinst. Skr. 146, 1-139+1:250,000 map.

Flood, B., Nagy, J. \& Winsnes, T. S. 1971: Geological Map of Svalbard. Sheet IG, Spitsbergen southern part. Scale 1:500,000. Norsk Polarinstitutt, Norsk Polarinst. Skr. 154A, (1 map sheet with text and bibliography).

Friend, P. F., Harland, W. B., Roger, D. A., Snape, I. \& Thorney, S. 1997: Late Silurian and Early Devonian stratigraphy and probable strike-slip tectonics in northwestern Spitsbergen. Geol. Mag. 134(4), 459-479.

Gavrilenko, B, V. \& Kamensky, I. L, 1992: K-Ar isochronyi vozrast $\mathrm{i}$ isotopy kalija $\mathrm{v}$ hyperbasitovoj dake na poluostrove Mossel, Ny Friesland, Spitsbergen. Geochim. 2, 124-129.

Gayer, R. A., Gee, D. G., Harland, W. B., Miller, J. A., Spall, H. R., Wallis, R. H. \& Winsnes, T. S. 1966: Radiometric age determinations on rocks from Spitsbergen. Norsk Polarinst. Skr. 137, $39 \mathrm{pp}$.

Gee, D. G. 1966: A note on the occurrence of eclogites in Spitsbergen. Norsk Polarinst. Arbok 1964, 240-241.

Gee, D. G. 1986: Svalbard's Caledonian terranes reviewed. Geol. Fören. Stockholm Förh. 108, 284-286.

Gee, D. G. 1989: Iapetus opening in the North Atlantic - along the axis of the Grenville Orogen? Geol. Fören. Stockholm Förh. 111, 383-385.

Gee, D. G. 1991: Caledonian terranes on Svalbard - new evidence of basement in Ny Friesland. Geonytt I8(I), 24, (abstract).

Gee, D. G. 1994: Svalbard's Caledonian terranes. Pp. 92-117 in Karlqvist \& Carlsson (eds.): Swedish Research in Svalbard. Stockholm: Swedish Polar Research Secretariat.

Gee, D. G. \& Hjelle, A. 1966: On the crystalline rock of northwest Spitsbergen. Norsk Polarinst. Arbok 1964, 31-45.

Gee, D. G. \& Moody-Stuart, M. 1966: The base of the Old Red Sandstone in central north Haakon VII Land, Vestspitsbergen. Norsk Polarinst. Årbok 1964, 57-68.

Gee, D. G. \& Page, L. M. 1994: Caledonian terrane assembly on Svalbard: new evidence from ${ }^{40} \mathrm{Ar} /{ }^{39} \mathrm{Ar}$ dating in $\mathrm{Ny}$ Friesland. Am. J. Sci. 294, 1166-1186.
Gee, D. G., Björklund, L. \& Stølen, L.-K. 1991: Thrust intercalation of early Proterozoic basement in the northeastern terrane (Ny Friesland) of Svalbard's Caledonides. In Terranes in the Arctic Caledonides, Troms $\phi$, 12-16 August 1991. Terra Abstracts 4, 17, (abstract).

Gee, D. G., Schouenborg, B., Peucat, J.-J., Abakumov, S. A., Krasil'shchikov, A. A. \& Teben'kov, A. M. 1992: New evidence of basement in the Svalbard Caledonides: Early Proterozoic zircon ages from Ny Friesland granites. Norsk Geol. Tidsskr. 72, 181-190.

Gee, D. G., Johansson, А., Ohta, Y. \& Teben'kov, A. 1993: The pre-Caledonian history of Nordaustlandet and Ny Friesland, Svalbard, Geonytt 93(1), 21-22.

Gee, D. G., Björkelund, L. \& Stølen, L.-K. 1994: Early Proterozoic basement in Ny Friesland - implications for the Caledonian tectonics of Svalbard. Tectonophys. 231, 171-182.

Gee, D. G., Johansson, A., Ohta, Y., Teben'kov, A. M., Krasil'shchikov, A. A., Balashov, Y. A., Larionov, A. N., Gannibal, L. F. \& Ryungenen, G. I. 1995: Grenvillian basement and a major unconformity within the Caledonides of Nordaustlandet, Svalbard. Precambrian Res. 70, 215-234.

Gee, D. G. \& Hellmann, F. 1996: Zircon Pb-evaporation ages from the Smutsbreen Formation, southern Ny Friesland: new evidence for Caledonian thrusting in Svalbards Eastern Terrane. Z. Geol. Wiss. 24(3/4), 429-439. Berlin.

Gjelsvik, T. 1979: The Hecla Hoek ridge of the Devonian Graben between Liefdefjorden and Holtedahlfonna, Spitsbergen. In Winsnes T. S. (ed.): The geological development of Svalbard during the Precambrian, Lower Palaeozoic, and Devonian. Symposium on Svalbard's geology. Oslo, 2-5 June, 1975. Norsk Polarinst. Skr. 167, 63-71.

Gorochov, I. M., Krasil'shchikov, A. A., Mel'nikov, N. N. \& Varsavskaya, E. S. 1977: Absolyutnyyvozrast (Rb-Sr) kvartsevykh profirov Kapp-Klansteenskoy Serii (Shpitsbergen) (Rb-Sr age of quartz porphyries of the Kapp Hansteen Series (Spitsbergen). Pp. 51-61 in Problemy Geochronologit $i$ Geochimil Izotopov (Problems of Geochronology and Geochemistry of Isotopes) Leningrad: Nauka (in Russian).

Gramberg, I. S., Krasil'shchikov, A. A. \& Semevskiy, D. V. 1990: Stratigraficheskiy slovar's Shpitsbergena (Stratigraphic Lexicon of Spitsbergen). Leningrad: Nedra. 203 pp. (in Russian).

Hamilton, E. I. \& Sandford, K. S. 1964: Rubidium-strontium ages from North-East Land (Spitsbergen). Nature 201, $1208-1209$.

Harland, W. B. 1941: Geological notes on the Stubendorff Mountains, West Spitsbergen. Pro. R. Soc. Edinb. B51(10), $119-129$.

Harland, W. B. 1959: The Caledonian sequence in $\mathrm{Ny}$ Friesland, Spitsbergen. Quart. J. Geol. Soc. 114, 307-342.

Harland, W. B. 1960: The development of Hecla Hoek rocks in Spitsbergen. Report of the XXI International Geological Congress, (Part XIX). Copenhagen: IGC. Pp. 1-16.

Harland, W. B. 1965: The tectonic evolution of the ArcticNorth Atlantic region. Pp. 59-75 in Blackett, P. M. S., Bullard, E. C. \& Runcorn, S. K. (eds.): A Symposium on Continental Drift. Philosophical Transactions of the Royal Society of London, Series A 258.

Harland, W. B. 1966: A hypothesis of continental drift tested against the history of Greenland and Spitsbergen. Camb. Res. $2,18-22$.

Harland, W. B. 1969: Contribution of Spitsbergen to understanding of tectonic evolution of North Atlantic region. 
North Atlantic Geology and Continental Drift. Memoirs of the American Association of Petroleum Geologists 12, 817-851.

Harland, W. B. 1971: Tectonic transpression in Caledonian Spitsbergen. Geol. Mag. 108(1), 27-42.

Harland, W. B. 1972: Early Palaeozoic faults as margins of Arctic plates in Svalbard. Proceedings of the 24th International Geological Congress, Montreal, Vol. 3, Montreal: IGC. Pp. 230-237.

Harland, W. B. 1973: Tectonic evolution of the Barents Shelf and related plates. Pp. 599-608 in Pitcher, M. (ed.): Arctic Geol. Mem. Am. Assoc. Petrol. Geol. 19, 599-608.

Harland, W. B. 1978: A reconsideration of Late Precambrian stratigraphy of southern Spitsbergen. Polarforsch. 48(1-2), 44-61.

Harland, W. B. 1985: Caledonide Svalbard. In The Caledonide Orogen - Scandinavia and Related Areas (eds Gee, D. G. and Sturt, B. A.), pp. 999-1016. Chichester: Wiley.

Harland, W. B. 1995: The Ny Friesland Orogen, Spitsbergen (reply to Manby \& Lyberis). Geol. Mag. 132(3), 351-356.

Harland, W. B. (in press): The Geology of Svalbard. Memoir 17. Geological Society of London. xxii $+522 \mathrm{pp}$.

Harland, W. B. \& Gayer, R. A. 1972: The Arctic Caledonides and earlier oceans. Geol. Mag. 109, 289-314.

Harland, W. B. \& Wilson, C. B. 1956: The Hecla Hoek succession in Ny Friesland, Spitsbergen. Geol. Mag. 93, 256-286.

Harland, W. B. \& Wright, N. J. R. 1979: Alternative hypothesis for the pre-Carboniferous evolution of Svalbard. In Winsnes T, S. (ed.): The geological development of Svalbard during the Precambrian, Lower Palaeozoic, and Devonian. Symposium on Svalbard's geology. Oslo, 2-5 June, 1975. Norsk Polarinst. Skr. 167, 89-117.

Harland, W. B., Wallis, R. H. \& Gayer, R. A. 1966: A revision of the lower Hecla Hoek succession in central north Spitsbergen and correlation elsewhere. Geol. Mag. 103(1), $70-97$.

Harland, W. B., Cutbill, J. L., Friend, P. F., Gobbett, D. J., Holliday, D. W., Maton, P. I., Parker, J. R. \& Wallis, R. H. 1974: The Billefjorden Fault Zone, Spitsbetgen: the long history of a major tectonic lineament. Norsk Polarinst. Skr. $161,72 \mathrm{pp}$.

Harland, W. B., Horsfield, W. T., Manby, G. M. \& Morris, A. P. 1979: An outline of the pre-Carboniferous stratigraphy of western Central Spitsbergen. In Winsnes T. S. (ed.): The geological development of Svalbard during the Precambrian, Lower Palaeozoic, and Devonian. Symposium on Svalbard's geology. Oslo, 2-5 June, 1975. Norsk Polarinst. Skr. 167, $119-144$

Harland, W. B., Scott, R. A., Auckland, K. A. \& Snape, I. 1992: The Ny Friesland Orogen, Spitsbergen. Geol. Mag. 129, 679-708

Harland, W. B., Hambrey, M. J. \& Waddams, P. 1993: The Vendian geology of Svalbard. Norsk Polarinst. Skr. 193, iv +150 .

Hellmann, F. J., Gee, D. G., Johansson, A. \& Witt-Nilsson, P. 1997: Single-zircon $\mathrm{Pb}$-evaporation geochronology constrains basement-cover relationships in the Lower Hecla Hoek Complex of northern Ny Friesland, Svalbard. Chem. Geol. 137, 117-134.

Henriksen, N. \& Higgins, A. K. 1976: East Greenland Caledonian Fold Belt. Pp. 182-246 in Escher, A. \& Watt, W. S. (eds.): The Geology of Greenland. Geological Survey of Greenland.
Hirajima, T., Banno, S., Hiroi, Y. \& Ohta, Y. 1988: Phase petrology of eclogites and related rocks from the Motalafjella high-pressure metamorphic complex in Spitsbergen (Arctic Ocean) and its significance. Lithos 22, 75-97.

Hjelle, A. 1978a: An outline of the Pre-Carboniferous geology of Nordaustlandet. Polarforsch. 48(1-2), 62-77.

Hjelle, A. 1978b: A preliminary report on the geology of Sjuøyane. Norsk Polarinst. Årbok 1977, 337-340.

Hjelle, A. 1979: Aspects of the geology of northwest Spitsbergen. In Winsnes T. S. (ed.): The geological development of Svalbard during the Precambrian, Lower Palaeozoic, and Devonian. Symposium on Svalbard's geology. Oslo, 2-5 June, 1975. Norsk Polarinst. Skr. 167, $37-62$

Hjelle, A. \& Lauritzen, Ø. 1982: Geological Map of Svalbard, 1:500,000. Spitsbergen Northern part Sheet 3G. Norsk Polarinst. Skr. 154C, (1 map sheet and $15 \mathrm{pp}$. text).

Hjelle, A., Ohta, Y. \& Winsnes, T. S. 1978: The geology of northeastern Svalbard. Norsk Polarinst. Årbok 1977, 7-24.

Hjelle, A., Ohta, Y. \& Winsnes, T. S. 1979: Hecla Hoek rocks of Oscar II Land and Prins Karls Forland, Svalbard. In Winsnes T. S. (ed.): The geological development of Svalbard during the Precambrian, Lower Palaeozoic, and Devonian. Symposium on Svalbard's geology. Oslo, 2-5 June, 1975. Norsk Polarinst. Skr. 167, 145-169.

Hjelle, A., Lauritzen, Ø., Salvigsen, O. \& Winsnes, T. S. 1986: Geological Map of Svalbard, 1:100,000. Sheet 10G Van Mijenfjorden. Norsk Polarinst. Temakart 2 (35 pp. + 1 map).

Holtedahl, O. 1912: Rapport sur ses traveaux au cours de l'expédition Isachsen au Spitsberg, en 1909-1910. In Rapport sur l'expédition Isachsen au Spitsberg 1909-1910 (ed. Isachsen, G.). Sk. Videnskabsselsk. Kristiania. Mat.Naturv 14, 86-88.

Holtedahl, O. 1914: New features in the geology of northwestern Spitzbergen. Am. J. Sci. 37, 415-424.

Holtedahl, O., 1920: On the Paleozoic series of Bear Island, especially the Hecla Hoek System. Norsk Geol. Tidsk. 5, $121-148$

Horsfield, W. T. 1972: Glaucophane schists of Caledonian age from Spitsbergen. Geol. Mag. 109, 29-36.

Johansson, Å., Gee, D. G., Björklund, L. \& Witt-Nilsson, P. 1995: Isotopic studies of granitoids from the Bangenhuk Formation, Ny Friesland Caledonides, Svalbard. Geol. Mag. 132(3), 303-320.

Kalsbeek, F. 1981: The northward extent of the Archean basement of Greenland - a review of Rb-Sr whole-rock ages. Precambrian Res. 14, 203-219.

Kalsbeek, F., Nutman, A. P. \& Taylor, P. N. 1993: Paleoproterozoic basement province in the Caledonian fold belt of North-East Greenland. Precambrian Research 63, $163-178$.

Knoll, A. H. 1982: Micro-fossil based biostratigraphy of the Precambrian Hecla-Hoek sequence, Nordaustlandet, Svalbard. Geol. Mag. 119(3), 269-279.

Knoll, A. H. \& Calder, S. 1983: Microbiotas of the Late Precambrian Ryssö Formation, Nordaustlandet, Svalbard. Palaeontol. 26(3), 467-496.

Knoll, A. H. \& Ohta, Y. 1988: Microfossils in metasediments from Prins Karls Forland, western Svalbard. Polar Res. 6, 59-67.

Knoll, A. H. \& Swett, K. 1985: Micropaleontology of the Late Proterozoic Veteranen Group, Spitsbergen. Palaeontol. $28(3), 451-473+$ plates. 
Knoll, A. H., Swett, K. \& Burkhardt, E. 1989: Paleoenviromnental distribution of microfossils and stromatolites in the Upper Proterozoic Backlundtoppen Formation, Spitsbergen. J. Paleontol. 63(2), 129-145.

Krasil'shchikov, A. A. 1965: Nekotorye Osobennosti geologichedkogo rasvitiya Severnoy chasti arkipelaga Shpitsbergen (Some aspects of the geological history of North Spitsbergen Archipelago). Pp. 29-44 in Sokolov, V. N. (ed.): Materialy po Geologii Shpitsbergena (Materials on the Geology of Spitsbergen). Leningrad: NIIGA (in Russian).

Krasil'shchikov, A. A. 1967: Tillitopodobiye porod severoVostochioy zemli (Tillite-like rocks of North East Land), Pp. 36-62 in Sokolov, V. N. (ed.): Materialy po stratigrafii Shpitsbergena. (Materials on the stratigraphy of Spitsbergen). NIIGA, Leningrad (in Russian).

Krasil'shchikov, A. A. 1970: Stratigraficheskaya skhema dokembrii i nizhnego paleozoya arkhipelaga Shpitsbergena (Scheme for the Precambrian and Lower Palaeozoic stratigraphy of the Spitsbergen Archipelago). Doklady Akademii Nauk SSSR 194(5), 1153-1156 (in Russian).

Krasil'shchikov, A. A. 1979: Stratigraphy and tectonics of the Precambrian of Svalbard. In Winsnes T. S. (ed.): The geological development of Svalbard during the Precambrian, Lower Palaeozoic, and Devonian. Symposium on Svalbard's geology. Oslo, 2-5 June, 1975. Norsk Polarinst. Skr. 167, 73-79.

Krasil'shchikov, A. A. \& Kovaleva, G. A. 1979: Precambrian rock-stratigraphic units of the west coast of Spitsbergen. In Winsnes T. S. (ed.): The geological development of Svalbard during the Precambrian, Lower Palaeozoic, and Devonian. Symposium on Svalbard's geology. Oslo, 2-5 June, 1975. Norsk Polarinst. Skr. 167, 81-88.

Krasil'shchikov, A. A. \& Livshits, Yu. Ya. 1974: Tectonics of Bear Island (Bjørnøya). Geotectonics 8(4), 215-221.

Krasil'shchikov, A. A. \& Mil'shtein, V. E. 1975: Ovozraste serii drevnikh dolomitov na o. Medvezh'i (Barentsovo more) (On the age of the "Series of Ancient Dolomites" on Bjørnøya (Barents Sea)). Dokl. Akad. Nauk SSSR 225(I), 161-163 (in Russian, transl. 1977).

Kuxling, O. 1934: Scientific results of the Swedish-Norwegian Arctic Expedition in the summer of 1931. Part XI. The "Hekla Hoek Formation" round Hinlopenstredet. Geogr. Ann. 16, 161-254.

Larionov A. N., Johansson, A., Teben'kov, A. M., \& Sirotkin, A. N. 1995: U-Pb zircon ages from the Eskolabreen Formation, southern Ny Friesland, Svalbard. Norsk Geol. Tidsskr. 75, 247-357.

Lauritzen, Ø. \& Ohta, Y. 1984: Geological Map of Svalbard, 1:500,000. Nordaustlandet Sheet 154G. Norsk Polarinst. Skr. $154 D$ ( 1 map sheet and 14 pp. text).

Major, H. \& Winsnes, T. S. 1955: Cambrian and Ordovician fossils from Sørkapp Land, Spitsbergen. Norsk Polarinst. Skr. 106. $47 \mathrm{pp}$.

Manby, G. M. 1983: A re-appraisal of chloritoid-bearing phyllites in the Forland Complex of Prins Karls Forland, Svalbard. Mineral. Mag. 47, 311-318.

Manby, G. M. 1986: Mid-Paleozoic metamorphism and polyphase deformation of the Forland Complex, Svalbard. Geol. Mag. 123(6), 651-663.

Manby, G. M. 1990: The petrology of the Harkerbreen Group, Ny Friesland, Svalbard: protoliths and tectonic significance. Geol. Mag. 127(2), 129-146.

Manby, G. M. \& Lyberis, N. 1991: Contrasting tectonometamorphic terranes in NE Svalbard: $\mathrm{Sm} / \mathrm{Nd}-\mathrm{Rb} / \mathrm{Sr}$ isotopic and structural constraints. $\mathrm{Pp}, 22-23$ in Terranes in the Arctic Caledonides, Troms $\phi, 12-16$ August 1991. Terra Abstracts 4 (abstract).

Manby, G. M. \& Lyberis, N. 1995: Discussion on the Ny Friesland Orogen, Spitsbergen. Geol. Mag. 132(3), 351-356.

Nathorst, A. G. 1910: Beitrage zur Geologie der Bären Insel, Spitzbergens und des König-Karl-Landes. Bul. Geol. Inst. Univ. Upps. 10, 261-416.

Nordenskiöld, A. E. 1863: Geografisk och geognostisk beskrifning öfver nordöstra delame af Spetsbergen och Hinlopen Strait. K. Svenska Vetenskapsakad. Handl. 4(7), $1-25$.

Nordenskiöld, A, E. 1866: Utkast till Spetsbergens geologi [Sketch of the geology of Spitzbergen]. $K$. Svenska Vetenskapsakad. Handl. 6(7), 1-35 (English translation published 1867, Norstedt, Stockholm).

Ohta, Y. 1978: Caledonian metamorphism in Svalbard, with some remarks on the basement. Polarforsch. 48(1-2), 78-91.

Ohta, Y. 1979: Blue schists from Motalafjella, western Spitsbergen. In Winsnes T. S. (ed.): The geological development of Svalbard during the Precambrian, Lower Palaeozoic, and Devonian. Symposium on Svalbard's geology. Oslo, 2-5 June, 1975. Norsk Polarinst. Skr. 167, $171-217$.

Ohta, Y. 1982: Hecla Hoek rocks in central and western Nordaustlandet. Polarinst. Skr. 178, $60 \mathrm{pp}$.

Ohta, Y. 1985: Geochemistry of the late Proterozoic Kapp Hansteen igneous rocks of Nordaustlandet, Svalbard. Polar Res. 3, 69-92.

Ohta, Y. 1988: Basement of W-Spitsbergen: an outline. Pp. 26-27 in Dallmann, W. K., Ohta, Y. \& Andresen, A. (eds.): Tertiary Tectonics of Svalbard. Norsk Polarinst, Report Series 46, 9-12 (extended abstract from symposium, 26-27 April 1988, Oslo)

Ohta, Y. 1992: Recent understanding of the Svalbard basement in the light of new radiometric age determinations. In Dallmann, W. K., Andresen, A. \& Krill, A. (eds.): PostCaledonian Tectonic Evolution of Svalbard. Norsk Geol. Tidsskr. 72(1), 1-6.

Ohta, Y, 1994: Caledonian and Precambrian history in Svalbard: a review and an implication of escape tectonics. Tectonophysics 231, 183-194.

Ohta, Y. \& Dallmann, W. K. 1992: Geological Map of Svalbard: 1:100,000 Sheet B12G, Torrellbreen. Norsk Polarinstitutt, Oslo.

Ohta, Y. \& Dallmeyer, R. D. 1986: Polyorogenic evolution of the Svalbard Caledonides and tectonic correlations with Northern Gronland and Arctic Canada. Geol. Soc. Am. Abstracts with Programs 18, 710.

Ohta, Y., Hiroi, Y. \& Hirajima, T. 1983: Additional evidence of pre-Silurian high-pressure metamorphic rocks in Spitsbergen. Polar Res. 1, 215-218.

Ohta, Y., Dallmeyer, R. D. \& Peucat, J. J. 1989: Caledonian terranes in Svalbard. In Circum-Atlantic Paleozoic Orogens (ed. Dallmeyer, R. D.). Spe. Pap. Geol. Soc. Am. 230, 1-15. Ohta, Y., Hjelle, A., Andresen, A., Dallmann, W. K. \& Salvigsen, O. 1992: Geological Map of Svalbard, 1:100,000. Sheet $B 9 G$ Isfjorden, with description. Norsk Polarinst. Temakart 16

Ohta, Y., Krasil'shchikov, A. A., Lepvrier, C. \& Teben'kov, A. M. 1995: Northern continuation of Caledonian high-pressure metamorphic rocks in central-western Spitsbergen. Polar Res. 14, 303-315. 
Ohta, Y., Peucat, J. J. \& Dallmeyer, R. D. 1991: Pre-Devonian terranes in Svalbard and Ellesmere Islands. In Terranes in the Arctic Caledonides, Troms $\phi, 12-16$ August 1991. Terra Abstracts 4, 24 (abstract).

Orvin, A. K. 1934: Geology of the Kings Bay region, Spitsbergen. Skr. Svalb. Ishavet 57, 195 pp.

Peucat, J. J., Tisserant, D., Caby, R. \& Clauer, N. 1985: Resistance of zircons to $\mathrm{U}-\mathrm{Pb}$ resetting in the prograde metamorphic sequence of Caledonian age in East Greenland. Can. J. Earth Sci. 22, 330-338.

Peucat, J. J., Ohta, Y., Gee, D. G. \& Bernard-Griffiths, J. 1989: $\mathrm{U}-\mathrm{Pb}, \mathrm{Sr}$ and $\mathrm{Nd}$ evidence for Grenvillian and latest Proterozoic tectonothermal activity in the Spitsbergen Caledonides, Arctic Ocean. Lithos 22, 275-285.

Rector, S. \& Bjørnerud, M. 1987: Quartz petrofabric and microstructural analysis of Antoniabreen Sequence rocks east of Recherchebreen, west Spitsbergen. Geol. Soc, Am., Abstracts with Programs 19, 814.

Sandford, K. S. 1926: The geology of North-East Land (Spitsbergen). Q. J. Geol. Soc. 82(4), 615-665.

Sandford, K. S. 1950: Observations on the geology of the northern part of North-East Land (Spitsbergen). Q. J. Geol. Soc. $105,461-491$.

Sandford, K. S. 1954: The geology of Isis Point, North-East Land (Spitsbergen). Q. J. Geol. Soc. 110(1), 11-20.

Sandford, K. S. 1956: The stratigraphy and structure of the Hecla Hoek Formation and its relationship to a subjacent metamorphic complex in North-East Land (Spitsbergen). $Q$. J. Geol. Soc. 112(3), 339-362.

Scrutton, C. T., Horsfield, W. T. \& Harland, W. B. 1976: Silurian fossils from western Spitsbergen. Geol. Mag. $113(6), 519-523$

Sokolov, V. N. 1965: Geologicheskiy ocherk arkhipelaga Shpitbergena (A geological sketch of Spitsbergen). Pp. 8-28 in Sokolov, V. N. (ed.): Materialy po Geologii Shpitsbergena (Materials on the geology of Spitsbergen), Leningrad: NIIGA (in Russian).

Suess, E. 1888: Das Antlitz der Erde (The Face of the Earth), Vol. 2 ( 5 volumes). Oxford (translation by Sollas, H. B. C., 1905).
Taylor, P. N., Kalsbeek, F. \& Bridgwater, D. 1992: Discrepancies between neodymium, lead and strontium model ages from the Precambrian of southern East Greenland: evidence for a Proterozoic granulite-facies event affecting Archean gneisses. Chem. Geol. 94, 284-291.

Teben'kov, A. M., Ohta, Y., Balashov, J. A. \& Sirotkin, A. N. 1996: Newtontoppen granitoid rocks; their geology, chemistry and Rb-Sr age. Polar Res. 15(1), 67-80.

Trettin, H. P. 1987: Pearya: a composite terrane with Caledonian affinities in northern Ellesmere Island. Can. $J$ Earth Sci. 24, 224-245.

Trettin, H. P., Parrish, R. R. \& Roddick, J. C. 1992: New U-Pb and $40 \mathrm{Ar}-30 \mathrm{Ar}$ age determinations from northern Ellesmere and Axel Heiberg islands, Northwest Territories and their tectonic significance. Geol. Sur. Can. Pap. 92(2), 3-30.

Turchenko, S. I., Barkhatov, D. B., Barmatenkov, I. I. \& Segreev, D. V. 1983: Geologicheskoye stroyeniye razreza zapadnogo berega Zemli Nordenskyolda (Geological structure of the west coast of Nordenskiöld Land). Pp. 1-15 in Krasil'shchikov, A. A. \& Basov, V. A. (eds.): Geologia Shpitsbergena: Sbornik Nauchnykhy stat'ey (Geology of Spitsbergen: a collection of scientific papers). Leningrad: "Sevmorgeo" (in Russian).

Tyrrell, G. W. 1922: The pre-Devonian basement complex of central Spitsbergen. Trans. R. Soc. Edinb. 53(1), 209-229.

Wallis, R. H. 1969: The Planetfjella Group of the lower Hecla Hoek of Ny Friesland, Spitsbergen. Norsk Polarinst. Arbok $1967,80-108$.

Wilson, C. B. 1958: The Lower Middle Hecla Hoek rocks of Ny Friesland, Spitsbergen. Geol. Mag. 95(4), 305-327.

Winsnes, T. S. 1988: Bedrock map of Svalbard and Jan Mayen. Scale 1: 1,000,000. Norsk Polarinst. Temakart 3 (12 pp. + 1 sheet).

Winsnes, T. S., Birkenmajer, K., Dallmann, W. K., Hjelle, A. \& Salvigsen, O. 1992: Geological Map of Svalbard, 1:100,000, Sørkapp Sheet CI3G. Norsk Polarinstitute, Oslo.

Winsnes, T. S. (ed.): The geological development of Svalbard during the Precambrian, Lower Palaeozoic, and Devonian. Symposium on Svalbard's geology. Oslo, 2-5 June, 1975. Norsk Polarinstitutt, Oslo. 

Preliminary Announcement

Mini-Conference

\title{
The Arctic Buoy Program
}

Scientific Achievements from the first 20 years

\author{
3-4 August, 1998 \\ Seattle, Washington, USA \\ sponsored by the \\ International Arctic Buoy Programme \\ and the \\ Data Buoy Co-operation Panel
}

Direct inquiries to:

Roger Colony or Tordis Villinger:

E-mail: acsys@npolar.no or tvilling@npolar.no

Phone: +4722959605 or +4722959573

Fax: +4722959601

or Thomas Thompson:

E-mail: thompson@sioc.se

Phone: +4738269635 (Mar-Nov)

+4652534101 (Dec-Feb)

\section{First Call for Papers}

The IABP invites abstracts for poster and oral presentations.

For further information see the following Web sites:

http://iabp.apl.washington.edu

http://www.npolar.no:80/acsys 


\section{Preliminary Announcement \\ Workshop}

\section{Operational Sea Ice Charts of the Arctic}

Scientific Achievements from the first 400 years

$$
\text { 5-7 August, } 1998
$$

Seattle, Washington, USA

sponsored by

ACSYS - Arctic Climate System Study of the World Climate Research Programme

\section{and the \\ US National Ice Center}

Direct inquiries to Roger Colony or Tordis Villinger:

E-mail: acsys@npolar.no or tvilling@npolar.no

Phone: +4722959605 or +4722959573

Fax: +4722959601

or to Thomas Thompson:

E-mail: thompson@sioc.se

Phone: +47 38269635 (Mar-Nov)

+4652534101 (Dec-Feb)

\section{First Call for Papers}

ACSYS and the US National Ice Center invite abstracts for poster and oral presentations.

For further information see the following Web sites:

http://iabp.apl.washington.edu

http://www.npolar.no:80/acsys 


\title{
International Symposium and Field Trip to Svalbard
}

\section{Polar Aspects of Global Change}

\author{
24-28 August, 1998 \\ Troms $\varnothing$, Norway
}

sponsored by

the International Arctic Science Committee (IASC) and the Scientific Committee on Antarctic Research (SCAR)

\author{
hosted by \\ the Norwegian Polar Institute and \\ the Polar Environmental Centre in Troms $\varnothing$
}

Sessions will focus on the following topics:

Climate trends in the Arctic and Antarctic

Teleconnections linking the polar regions to low- and mid-latitudes

Terrestrial systems and feedback on climate change

Variability of polar snow, ice and permafrost features

Ice sheet and glacier mass balance and sea level

Biogeochemical cycles in the Arctic and Antarctic

The circumpolar Arctic/Antarctic paleoenvironmental record

Atmospheric chemistry, ozone and UV-B effects

Regional and socio-economic impacts of global change

For further information and a copy of the Second Circular, contact:

Polar Aspects of Global Change

c/o Norsk Polarinstitutt

N-9005 Troms $ø$, Norway

E-mail: jaklin@tromso.npolar.no

Phone: +47 776067 00; Fax: +47 77606701

Web site: http://www.tromso.npolar.no 


\title{
Conference Announcement
}

International Co-operation in Arctic Research-Detecting Global Change and its Impacts in the Western Arctic

\section{$49^{\text {th }}$ Arctic Division Science Conference}

\author{
25-28 October, 1998
}

Fairbanks, Alaska, USA

sponsored by the

American Association for the Advancement of Science (AAAS)

Session themes:

International Collaboration in Global Change Reseach in the Arctic Ocean-Atmosphere-Ice Interactions

Land-Atmosphere-Ice Interactions

Paleoclimates

Regional Impacts of Climate Change

Global Implications of a Changing Arctic

For more information contact:

Syun-Ichi Akasofu, Conference Chair, +1-907-474-7282

Ted DeLaca, Program Chair, +1-907-474-7314

Jan Dalrymple, Coordinator, +1-907-474-6742 or

Mary Farrell, Coordinator, fnmrf@uaf.edu

Geophysical Institute, University of Alaska Fairbanks,

Fairbanks, Alaska 99775-7320, USA

Fax: +1 907-474-5882

or visit us at http://www.gi.alaska.edw 